\title{
СОВРЕМЕННОЕ ВАЛЮТНОЕ РЕГУЛИРОВАНИЕ В РОССИЙСКОМ ЗАКОНОДАТЕЛЬСТВЕ
}

\begin{abstract}
Аннотация: В настоящей статье рассматриваются вопросы, посвященные основныл категориям и механизму регулирования валютных отношений нормами российского законодательства. Существующая система нормативно-правовых актов России представляет собой юридический механизм регулирования валютных отношений, имеющий двойное функциональное назначение. Во-первых, он выполняет статическую функцию, закрепляя уже сложившийся комплекс валютных отношений; во-вторых, ему присуща динамическая функция, которая выражается в том, что создаются предпосылки для дальнейшего развития и трансформации данного комплекса, т.е. возможность его видоизменения. Валютное законодательство представляет собой первый структурный элемент механизма валютного регулирования, и именно оно выполняет регулятивную функцию в этом механизме. Валютные отношения как второй структурный элемент механизма валютного регулирования не представляют собой однородноймассы, а в свою очередь, имеют логическую систему построения, включаюшую субъекть, объекты и валютные операции, т.е. действия, которые субъекты валютных отношений имеют право совершать применительно к объектам. Регулятивное воздействие валютного законодательства на валютные отношения, осуществляемое в различных формах (в форме предписаний, дозволений и запретов, осуществления валютного контроля и возложения ответственности на субъектов валютньх отношений за нарушение ими норм валютного законодательства), можно рассматривать как третий структурный элемент механизма валютного регулирования. В статье с помощью сравнительного и формально-логического методов исследования автором проведен детальный анализ норм и механизмов правовой регламентации валютных отношений, содержсащихся в российском законодательстве, представленном Федеральным законом «О валютном регулировании и валютном контроле» 2003 года, другими законами и подзаконными нормативньлми актами. Анализ содержания норм российского законодательства позволил автору утверждать, что валютное регулирование и валютныи контроль как составная часть регулирующего механизма объективно способствуют поддержанию сбалансированного движения финансовых потоков в экономике страны и, как следствие этого, достижению стабильного функционирования банковской системы, через которую движение финансовых ресурсов реально осуществляется. Валютные операции являются важнейшей составляющей валютных отношений как структурного элемента валютного регулирования и представляют собой комплекс действий резидентов и нерезидентов, совершаемьх с валютой и ценными бумагами, как правило, в форме различного рода сделок, существенной чертой которых выступает движение валюты и ценных бумаг в виде перехода права собственности на них и/или их физического перемещения. Все валютные операции можно классифицировать по трем основаниям - по содержанию, по форме и по субъектному составу.

Abstract: The article concerns the issues of main categories and mechanism for the regulation of currency relation by the norms of the Russian legislation. The existing system of Russian normative legal acts is a legal mechanism for the regulation of currency relations of dual functional purpose. Firstly, it serves a statistical function, providing for the existing complex of currency relations. Secondly, it has a dynamic function, by which it provides prerequisites for the further development and transformation of this complex, that is the possibility for changing it. The currency legislation is the first structural element of the mechanism of currency regulation, and it serves a regulatory function in this mechanism. The currency relations as a second structural element of currency regulation are not uniform, they have a logical formation system, including subjects, objects and currency operations, that is, the acts which the subjects of currency relations may undertake towards the objects. The regulatory influence of the currency legislation upon the currency relations is implemented in various forms (orders, permissions and prohibitions, currency control, responsibility of subjects of cur-
\end{abstract}




\section{Системы стабилизации: финансовый контроль}

rency regulation for the violation of the currency legislation, which may be regarded as the third structural element for the mechanism of legal regulation. In the article with the help of comparative and formal legal methods of studies the author provides a detailed analysis of norms and mechanisms for the legal regulation of currency relations in the Russian legislation, as provided for by the Federal Law 'On Currency Regulation and Currency Control' of 2003, other laws and bylaws. Analysis of the norms of Russian legislation allows the author to state that currency regulation and currency control as elements of the regulating mechanism objectively facilitate and support balanced capital flow in the national economy, and, therefore, achievement of the sustainable functioning of the banking system, through which the movement of financial resources is really implemented. The currency operations form an important element of currency relations as a structural element of currency regulation, being a complex of activities of resident and non-resident entities, which are performed with the currency and security, usually in the form of various deals. Their fundamental characteristic feature is movement of currency and securities via transfer of proprietary title to them and (or) their physical movement. All of the currency operations may be classified based upon the three grounds: their contents, their forms, subject elements.

Ключевые слова: валютное регулирование, валютное законодательство, валютный контроль, валютные отношения, иностранная валюта, внешние ценные бумаги, валютные операции, резиденты и нерезиденты, валютный банковский счет, перемещение валютных иенностей.

Keywords: currency regulation, currency legislation, currency control, currency relations, foreign currency, foreign securities, currency operations, residents and non-residents, foreign currency bank account, movement of currency values.

анковское регулирование как система норм государственно-властного характера, имеющее целью ограничение и упорядочение банковской деятельности, в любом обществе представлено в двух видах - пруденциального и валютного регулирования. Пруденциальное регулирование имеет своей целью обеспечение стабильного и надежного функционирования банковской системы государства в целом, а также защиту интересов вкладчиков. Эта цель достигается с помощью государственной регистрации банков и лицензирования банковской деятельности, установления экономических нормативов функционирования банков, а также осуществления банковского надзора, главным инструментом которого выступает применение мер воздействия (санкций) со стороны государства.

Целью валютного регулирования является проведение разумной денежно-кредитной политики в условиях рыночной экономики, которая выступает инструментом достижения макроэкономических целей государства. В этом смысле можно утверждать, что валютное регулирование и валютный контроль как составная часть регулирующего механизма объективно способствуют поддержанию сбалансированного движения финансовых потоков в экономике страны и, как следствие этого, достижению стабильного функционирования банковской системы, через которую движение финансовых ресурсов реально осуществляется ${ }^{1}$. Таким образом, несмотря на разницу в целях, оба вида бан-

\footnotetext{
${ }^{1}$ См.: Тедеев A.A. Тенденции формирования правовых принципов валютного регулирования // Евразийский юридический журнал. 2012. № 5 .
}

ковского регулирования имеют один и тот же результат в своем действии, выражающийся в оптимизации функционирования банков и других кредитных организаций, выполняющих банковских функции²

\section{1) Структура механизма валютного регулирования: правовые основы}

Переход российской экономики на рыночные отношения, ее постепенная интеграция в мировое хозяйство и международные валютно-финансовые организации, последовательная децентрализация внешнеэкономических связей российских предприятий с зарубежными партнерами делают крайне актуальными знания механизма регулирования валютных отношений на территории России и за ее пределами. Данный механизм, имеющий экономическую природу (в его основе лежат объективно обусловленные экономические процессы), выступает в любом государстве в правовой форме.

Существующая система нормативно-правовых актов представляет собой юридический механизм регулирования валютных отношений, имеющий двойное функциональное назначение. Во-первых, он выполняет статическую функцию, закрепляя уже сложившийся комплекс валютных отношений; во-вторых, ему прису-

\footnotetext{
${ }^{2}$ В теоретическом контексте валютное регулирование представляет собой предмет валютного права, которое рассматривается отечественной юридической наукой как комплексная отрасль национальной правовой системы. См.: Алексеева Д.Г., Пыхтин С.В., Сапожников Н.В., Фальковская Я.М. Валютное право: Учебное пособие для магистров. М., 2013; Крохина Ю.А. (ред.) Валютное право: Учебник для магистров. М., 2013.
} 
DOI: $10.7256 / 1811-9018.2014 .5 .11920$

При цитировании этой статьи сноска на dоі обязательна

\section{Право и политика 5 (173) • 2014}

ща динамическая функция, которая выражается в том, что создаются предпосылки для дальнейшего развития и трансформации данного комплекса, т.е. возможность его видоизменения. Следует подчеркнуть, что вне рамок существующей системы нормативно-правовых актов вообще невозможно говорить о механизме регулирования валютных отношений в любом государстве. В научной литературе вышеупомянутая система получила название «валютное законодательство». Этот термин употребляется в широком смысле и охватывает не только законы, но и любые другие подзаконные акты нормативного характера (указы Президента РФ, постановления Правительства РФ, инструкции Центрального банка РФ и т.д.). Механизм валютного регулирования можно представить на следующей схеме:
Структурные элементы механизма валютного регулирования находятся в постоянном взаимодействии и взаимовлиянии, что предполагает их системообразующее видоизменение и функциональное эволюционирование. Статичные по сути валютные отношения, представляющие собой константу механизма валютного регулирования, перманентно находятся в состоянии развития в силу регулятивного воздействия на них со стороны динамичного по сути валютного законодательства, играющего в силу своей особенности роль двигателя в данном механизме.

Валютное законодательство представляет собой первый структурный элемент механизма валютного регулирования, и именно оно выполняет регулятивную функцию в этом механизме ${ }^{4}$. Валютное законодатель-

\begin{tabular}{|c|c|c|}
\hline $\begin{array}{l}\text { Валютное } \\
\text { законодательство }\end{array}$ & Регулятивное воздействие & Валютные отношения \\
\hline \multirow[t]{2}{*}{$\begin{array}{l}\text { Акты валютного } \\
\text { законодательства } \\
\text { (нормативный аспект) }\end{array}$} & \multirow{3}{*}{$\begin{array}{l}\text { Валютное законодательство осуществляет } \\
\text { регулятивное воздействие на валютные } \\
\text { отношения в форме предписаний, } \\
\text { дозволений и запретов, осуществления } \\
\text { валютного контроля и возложения } \\
\text { ответственности на субъектов валютных } \\
\text { отношений за нарушение ими норм } \\
\text { валютного законодательства }\end{array}$} & Субъекты валютных отношений \\
\hline & & Объекты валютных отношений \\
\hline $\begin{array}{l}\text { Органы, издающие } \\
\text { акты валютного } \\
\text { законодательства } \\
\text { (институционный аспект) }\end{array}$ & & Валютные операции \\
\hline
\end{tabular}

Как видно из вышеприведенной схемы, механизм валютного регулирования включает в себя три структурных элемента:

1. Валютное законодательство, принимаемое различными государственными органами;

2. Валютные отношения, складывающиеся между различными субъектами по поводу совершения ими валютных операций с различными объектами;

3. Регулятивное воздействие валютного законодательства на валютные отношения, осуществляемое в различных формах.

\footnotetext{
3 Регулятивное воздействие всегда предполагает наличие элемента принуждения в регулятивном механизме, который выражается, главным образом, в юридической ответственности субъектов валютных отношений за совершаемые ими действия. См.: Сатарова Н.A. Принуждение в механизме валютно-правового регулирования // Банковское право. 2006. № 2.
}

ство РФ в настоящее время представляет собой крайне неоднородный нормативный комплекс, включающий акты различной юридической природы, принятые государственными органами, которые находятся на различных ступеньках государственной иерархии. Согласно Конституции РФ от 12 декабря 1993 г. в ред. от 05 февраля 2014 г. ${ }^{5}$ валютное регулирование находится в ведении Российской Федерации (п. Ж ст. 71). Это означает, что принятие валютного законодательства входит в исключительную компетенцию федеральных государственных органов и не находится в компетенции субъектов РФ.

\footnotetext{
${ }^{4}$ См.: Миттельман К.Г. К вопросу о проблеме совершенствования понятийного аппарата валютного законодательства // Государство и право. 2012. № 8.

${ }^{5}$ С3 РФ. 2014. № 9. Ст. 851. Новая редакция Конституции РФ вступила в силу с 06 февраля 2014 г.
} 


\section{Системы стабилизации: финансовый контроль}

Основным актом валютного законодательства является Федеральный закон «О валютном регулировании и валютном контроле» от 10 декабря 2003 г. в ред. от 12 марта 2014 г. ${ }^{6}$ (далее - Закон). Закон состоит из пяти глав, логически связанных между собой (Глава 1 «Общие положения»; Глава 2 «Валютное регулирование»; Глава 3 «Репатриация резидентами иностранной валюты и валюты РФ и обязательная продажа части валютной выручки»; Глава 4 «Валютный контроль» и Глава 5 «Заключительные положения»). Последняя редакция Закона содержит большое число новелл правовой регламентации, что позволяет говорить о введении в России кардинально иного механизма валютного регулирования взамен существовавшего ранее 7 . Во-первых, в Законе впервые четко сформулированы основные принципы валютного регулирования и валютного контроля, к числу которых относятся:

1) приоритет экономических мер в реализации государственной политики в области валютного регулирования;

2) исключение неоправданного вмешательства государства и его органов в валютные операции резидентов и нерезидентов;

3) единство внешней и внутренней валютной политики РФ;

4) единство системы валютного регулирования и валютного контроля;

5) обеспечение государством защиты прав и экономических интересов резидентов и нерезидентов при осуществлении валютных операций ${ }^{8}$ (ст. 3).

Во-вторых, в Законе по-новому обозначены органы валютного регулирования, в число которых ныне входят Центральный банк РФ и Правительство РФ, причем последнему отводится весьма важная роль

${ }^{6}$ СЗ РФ. 2003. № 50. Ст. 4859; 2014. № 11. Ст. 1098. Новая редакции Закона вступила в силу с 12 марта 2014 г.

${ }^{7}$ См.: Кораблин В.В. Перспективы изменений в валютном законодательстве с учетом вступления Российской Федерации во Всемирную торговую организацию // Законодательство. 2013. № 2; Кораблин В.В. Перспективы изменений в валютном законодательстве с учетом формирования Единого экономического пространства // Законодательство. 2013. № 4; Селивановский А.С. Новое валютное законодательство: суть понятий // Закон. 2005. № 4; Эрделевский А.М. Об изменениях в валютном законодательстве России // Деньги и кредит. 2007. № 2.

${ }^{8}$ См: Красавина Л.Н. Актуальные проблемы валютной политики России // Банковское дело. 2013. № 3; Крохина Ю.А. Актуальные проблемы законодательного обеспечения принципов валютного регулирования и валютного контроля // Российское правосудие. 2010. № 7. в принятии актов валютного регулирования (ст. 5)9. В-третьих, в Законе по-иному определены методы регулирования валютных операций, в число которых входят требование о репатриации резидентами иностранной валюты и валюты РФ (ст. 19), а также требование о совершении резидентами и нерезидентами валютных операций через банковские счета, открытые в уполномоченных банках (ст. 13-14).

Акты валютного законодательства в широком смысле слова включают в себя наряду с законами и акты органов валютного регулирования (Центрального банка РФ и Правительства РФ), а также нормативно-правовые акты федеральных органов исполнительной власти, принятые в пределах их компетенции. Акты валютного законодательства применяются к отношениям, возникшим после вступления указанных актов в силу, за исключением случаев, прямо предусмотренных законом. К отношениям, возникшим до вступления в силу соответствующих актов валютного законодательства, указанные акты применяются в части прав и обязанностей, возникших после вступления их в силу.

Акты валютного законодательства, устанавливающие новые обязанности для резидентов и нерезидентов или ухудшающие их положение, обратной силы не имеют. Акты валютного законодательства, отменяющие ограничения на осуществление валютных операций или иным образом улучшающие положение резидентов и нерезидентов, могут иметь обратную силу, если прямо предусматривают это. Акты валютного законодательства подлежат официальному опубликованию. Неопубликованные акты не применяются.

Органы валютного контроля могут издавать акты валютного контроля по вопросам, отнесенным к их компетенции, только в случаях и пределах, предусмотренных валютным законодательством. Акты органов валютного контроля не должны содержать положения, касающиеся вопросов регулирования валютных операций. Все неустранимые сомнения, противоречия и неясности актов валютного законодательства и актов органов валютного контроля толкуются в пользу резидентов и нерезидентов (п. 3-6 ст. 4).

Выступая как органы валютного регулирования, Банк России и Правительство РФ обладают нормотворческой

\footnotetext{
${ }^{9}$ Интересно отметить, что Центральный банк РФ, Правительство РФ, а также специально уполномоченные на то Правительством РФ федеральные органы исполнительной власти осуществляют все виды валютных операций без ограничений (п. 5 ст. 5). В качестве последних выступают Министерство обороны РФ, Министерство иностранных дел РФ, Федеральная служба безопасности РФ, Служба внешней разведки РФ, Федеральное казначейство.
} 


\section{Право и политика $5(173) \cdot 2014$}

функцией, то есть вправе издавать в пределах своей компетенции нормативно-правовые акты, обязательные для резидентов и нерезидентов. Закон различает исключительную компетенцию Банка России, исключительную компетенцию Правительства РФ и совместную компетенцию Банка России и Правительства РФ по принятию актов валютного законодательства. Так, например, нерезиденты на территории РФ вправе открывать банковские счета (банковские вклады) в иностранной валюте и валюте РФ только в уполномоченных банках. Порядок открытия и ведения банковских счетов (банковских вкладов) нерезидентов, открываемых на территории РФ, в том числе специальных счетов, устанавливает Банк России (п. 1-2 ст. 13). Расчеты при осуществлении валютных операций производятся юридическими лицами-резидентами через банковские счета в уполномоченных банках, порядок открытия и ведения которых устанавливается Банком России (п. 2 ст. 14). Расчеты при осуществлении валютных операций производятся физическими лицами-резидентами через банковские счета в уполномоченных банках, порядок открытия и ведения которых устанавливается Банком России (п. 3 ст. 14).

Валютный контроль в России осуществляется Правительством РФ, органами и агентами валютного контроля. Органами валютного контроля являются Банк России, федеральный орган исполнительной власти, уполномоченный Правительством РФ (в настоящее время таким органом является Федеральная служба финансово-бюджетного надзора). Агентами валютного контроля являются уполномоченные банки и не являющиеся уполномоченными банками профессиональные участники рынка ценных бумаг, а также государственная корпорация «Банк развития и внешнеэкономической деятельности (Внешэкономбанк)», таможенные органы и налоговые органы ${ }^{10}$. Контроль за осуществлением валютных операций кредитными организациями осуществляет Банк России. Контроль за осуществлением валютных операций резидентами и нерезидентами, не являющимися кредитными организациями, осуществляют в пределах своей компетенции федеральные органы исполнительной власти, являющиеся органами валютного контроля, и агенты валютного контроля ${ }^{11}$.

\footnotetext{
${ }^{10}$ См.: Ивашкова T.B. Выявление и профилактика нарушений валютного законодательства // Международные банковские операции. 2011. № 1; Новикова И.П. Финансово-правовой статус органов валютного регулирования и валютного контроля // Государство и право. 2009. № 10.

${ }^{11}$ См.: Владимиров И.П. Валютный контроль за операциями физических лиц в современных условиях // Международные банковские операции. 2010. № 4.
}

Правительство РФ обеспечивает координацию деятельности в области валютного контроля федеральных органов исполнительной власти, являющихся органами и агентами валютного контроля, а также их взаимодействие с Центральным банком РФ. Правительство РФ обеспечивает взаимодействие таможенных и налоговых органов как агентов валютного контроля с Банком России $^{12}$ (п. 1-6 ст. 22). Резиденты, за исключением физических лиц-резидентов, дипломатических представительств, консульских учреждений РФ и иных официальных представительств РФ, находящихся за пределами территории РФ, а также постоянных представительств РФ при межгосударственных и межправительственных организациях, представляют налоговым органам по месту своего учета отчеты о движении средств по счетам (вкладам) в банках за пределами территории РФ с подтверждающими банковскими документами в порядке, устанавливаемом Правительством РФ по согласованию с Банком России (п. 7 ст. 12) ${ }^{13}$.

Акты валютного законодательства принимаются Банком России в форме инструкций, положений и указаний, а Правительством РФ - в форме постановлений и распоряжений. Акты валютного законодательства, принимаемые федеральными органами исполнительной власти в пределах их компетенции, имеют форму главным образом приказов, инструкций и положений. Порядок их принятия и регистрации регулируется Правилами подготовки нормативных правовых актов федеральных органов исполнительной власти и их государственной регистрации, утвержденными Постановлением Правительства РФ № 1009 от 13 августа 1997 г. в ред. от 17 февраля 2014 г. $^{14}$

Согласно этому документу нормативные правовые акты федеральных органов исполнительной власти издаются на основе и во исполнение федеральных законов, указов и распоряжений Президента РФ, постановлений и распоряжений Правительства РФ, а также по их инициативе в пределах их компетенции (п. 1). Нормативные правовые акты издаются феде-

\footnotetext{
${ }^{12}$ См.: Постановление Правительства РФ № 166 «О порядке представления органами и агентами валютного контроля в орган валютного контроля, уполномоченный Правительством РФ, необходимых для осуществления его функций документов и информации» от 24 февраля 2009 г. (СЗ РФ. 2007. № 9. Ст. 1129).

${ }^{13}$ См.: Постановление Правительства РФ № 819 «Об утверждении Правил представления резидентами налоговым органам отчетов о движении средств по счетам (вкладам) в банках за пределами территории РФ» от 28 декабря 2005 г. в ред. от 25 декабря 2012 г. (СЗ РФ. 2006. № 2. Ст. 188; 2012. № 53 (ч. 2). Ст. 7951).

${ }^{14}$ СЗ РФ. 1997. № 33. Ст. 3895; 2014. № 8. Ст. 816. Новая редакция настоящего постановления вступила в силу с 28 февраля 2014 г.
} 
ральными органами исполнительной власти в виде постановлений, приказов, распоряжений, правил, инструкций и положений. Издание таких актов в виде писем и телеграмм не допускается ${ }^{15}$. Структурные подразделения и территориальные органы федеральных органов исполнительной власти не вправе издавать нормативные правовые акты (п. 2).

Акты валютного законодательства, принимаемые Президентом РФ как органом общей компетенции в области валютного регулирования в форме указов, представляют собой в настоящее время весьма узкую группу актов. В качестве примера можно привести Указ Президента РФ № 1634 «Об освобождении нефтегазодобывающих объединений от обязательной продажи части валютной выручки при поставках нефти для погашения иностранного кредита» от 15 октября 1993 г. ${ }^{16}$ Такое положение вещей обусловлено тем фактом, что большая группа валютных операций с драгоценными металлами и драгоценными камнями, регулирование которых входило ранее в компетенцию Президента РФ, ныне вообще выведена из сферы валютного регулирования и рассматривается как группа операций на финансовом рынке.

Наряду с нормативным аспектом, представленным актами валютного законодательства, в структуре механизма валютного регулирования можно выделить и институционный аспект. Он представлен теми государственными органами, которые осуществляют принятие актов валютного законодательства и контроль за их соблюдением. Такие государственные органы выступают как органы специальной компетенции в области валютного регулирования. Наделение Законом Банка России и Правительства РФ функций по принятию актов валютного законодательства означает придание им статуса органов специальной компетенции. Институционный аспект механизма валютного регулирования схематично можно представить следующим образом:

\begin{tabular}{|c|l|l|}
\hline $\begin{array}{c}\text { №oo } \\
\text { п/п }\end{array}$ & $\begin{array}{c}\text { Наименование государственного } \\
\text { органа }\end{array}$ & \multicolumn{1}{|c|}{$\begin{array}{c}\text { Правовая основа функционирования государственного } \\
\text { органа }\end{array}$} \\
\hline 1. & $\begin{array}{l}\text { Центральный банк РФ (Банк } \\
\text { России) }\end{array}$ & $\begin{array}{l}\text { Ф3 «О Центральном банке РФ (Банке России)» от } 10 \text { июля } \\
2002 \text { г. в ред. от } 28 \text { декабря } 2013 \text { г. }{ }^{17}\end{array}$ \\
\hline 2. & Федеральная таможенная служба & $\begin{array}{l}\text { Положение о Федеральной таможенной службе, утв. } \\
\text { Постановлением Правительства РФ № } 459 \text { от } 26 \text { июля } 2006 \text { г. } \\
\text { в ред. от } 16 \text { сентября } 2013 \text { г. }{ }^{18}\end{array}$ \\
\hline 3. & Федеральная налоговая служба & $\begin{array}{l}\text { Положение о Федеральной налоговой службе, утв. } \\
\text { Постановлением Правительства РФ № } 506 \text { от } 30 \text { сентября } 2004 \text { г. } \\
\text { в ред. от 02 ноября 2013 г. }{ }^{19}\end{array}$ \\
\hline 5. & $\begin{array}{l}\text { Федеральная служба по } \\
\text { финансовому мониторингу }\end{array}$ & $\begin{array}{l}\text { Положение о Федеральной службе по финансовому } \\
\text { мониторингу, утв. Указом Президента РФ № } 808 \text { от } 13 \text { июня } \\
\text { 2012 г. в ред. от } 21 \text { декабря 2013 г. }{ }^{20}\end{array}$ \\
\hline
\end{tabular}

\footnotetext{
${ }^{15}$ В нарушение данного требования Правил сохраняется практика принятия нормативных правовых актов в виде писем, которым ввиду очевидного несоответствия требованиям Правил стараются придать методический или рекомендательный характер. См., например, Письмо ФТС № 01-11/217 «О направлении методических рекомендаций по квалификации нарушений валютного законодательства» от 10 января 2008 г. в ред. от 05 октября 2012 г. (Таможенный вестник. 2008. № 3).

${ }^{16}$ САПП РФ. 1993. № 42. Ст. 3996.

${ }^{17}$ СЗ РФ. 2002. № 28. Ст. 2790; 2013. № 52 (ч. 1). Ст. 6975.

${ }^{18}$ С3 РФ. 2006. № 32. Ст. 3569; 2013. № 38. Ст. 4823.

${ }^{19}$ СЗ РФ. 2004. № 40. Ст. 3961; 2013. № 45. Ст. 5832.

${ }^{20}$ СЗ РФ. 2012. № 25. Ст. 3314; 2013. № 52 (ч. 2). Ст. 7137.
}

Валютные отношения как структурный элемент механизма валютного регулирования не представляют собой однородной массы, а в свою очередь, имеют логическую систему построения, включающую субъекты, объекты и валютные операции, то есть действия, которые субъекты валютных отношений имеют право совершать применительно к объектам ${ }^{21}$. Специфика валютного законодательства состоит в том, что общеправовые категории субъектов не совсем подходят к данному вопросу. Валютное законодательство использует совершенно новые категории субъектов, неизвест-

\footnotetext{
${ }^{21}$ См.: Емелин А.В. Основы правового регулирования валютных отношений // Закон. 2005. № 4; Смирникова Ю.Л. Валютные правоотношения как элемент механизма финансово-правового регулирования // Международное публичное и частное право. 2006. № 6 .
} 
DOI: $10.7256 / 1811-9018.2014 .5 .11920$

При цитировании этой статьи сноска на dоі обязательна

\section{Право и политика $5(173) \cdot 2014$}

ные гражданскому праву в целом, а именно, резиденты и нерезиденты. Важность выделения этих категорий субъектов заключается в том, что в зависимости от их вида различается правовой режим осуществления ими валютных операций. Закон включает в категорию резидентов следующих лиц:

- $\quad$ физические лица, являющиеся гражданами РФ, за исключением граждан РФ, постоянно проживающих в иностранном государстве не менее одного года, в том числе имеющих выданный уполномоченным государственным органом соответствующего иностранного государства вид на жительство, либо временно пребывающих в иностранном государстве не менее одного года на основании рабочей визы или учебной визы со сроком действия не менее одного года или на основании совокупности таких виз с общим сроком действия не менее одного года;

- $\quad$ постоянно проживающие в РФ на основании вида на жительство иностранные граждане и лица без гражданства;

- $\quad$ юридические лица, созданные в соответствии с законодательством РФ;

- $\quad$ находящиеся за пределами территории РФ филиалы, представительства и иные подразделения юридических лиц-резидентов;

- дипломатические представительства, консульские учреждения РФ и иные официальные представительства РФ, находящиеся за пределами территории РФ, а также постоянные представительства РФ при межгосударственных или межправительственных организациях;

- Российская Федерация, субъекты РФ, муниципальные образования, которые вступают в валютные отношения (п. 1(6) ст. 1).

К нерезидентам Закон относит следующих лиц:

- $\quad$ физические лица, не являющиеся резидентами;

- юридические лица, созданные в соответствии с законодательством иностранных государств и имеющие местонахождение за пределами территории РФ;

- организации, не являющиеся юридическими лицами, созданные в соответствии с законодательством иностранных государств и имеющие местонахождение за пределами территории РФ;

- $\quad$ аккредитованные в РФ дипломатические представительства, консульские учреждения иностранных государств и постоянные представительства указанных государств при межгосударственных или межправительственных организациях;
- $\quad$ межгосударственные и межправительственные организации, их филиалы и постоянные представительства в РФ;

- $\quad$ находящиеся на территории РФ филиалы, постоянные представительства и другие обособленные или самостоятельные структурные подразделения нерезидентов - юридических лиц и организаций, не являющихся юридическими лицами;

- $\quad$ иные лица, не являющиеся резидентами (п. 1(7) ст. 1). Закон не раскрывает в деталях характеристики резидентов и нерезидентов ${ }^{22}$, поэтому для точного уяснения сути этих категорий необходимо обращаться к иным нормативно-правовым актам. Так, Закон относит к резидентам физических лиц - иностранных граждан и лиц без гражданства, которые постоянно проживают в России на основании вида на жительство. Этот вопрос регулируется Федеральным законом «О правовом положении иностранных граждан в РФ» от 25 июля 2002 г. в ред. от 28 декабря 2013 г. ${ }^{23}$ Согласно данному закону все иностранные граждане, находящиеся на территории России, делятся на три категории:

- $\quad$ временно пребывающие в России;

- $\quad$ временно проживающие в России;

- $\quad$ постоянно проживающие в России (п. 1 ст. 2).

В каждом из трех случаев предусмотрены определенные основания и сроки нахождения иностранных граждан на территории России. Срок временного пребывания иностранного гражданина в РФ определяется сроком действия выданной ему визы. Срок временного пребывания в РФ иностранного гражданина, прибывшего в РФ в порядке, не требующем получения визы, не может превышать девяносто суток (п. 1 ст. 5). Разрешение на временное проживание может быть выдано иностранному гражданину в пределах квоты, утвержденной Правительством РФ. Срок действия разрешения на временное проживание составляет три года (п. 1 ст. 6).

В течение срока действия разрешения на временное проживание и при наличии законных оснований иностранному гражданину по его заявлению может быть выдан вид на жительство. Заявление о выдаче вида на жительство подается иностранным гражданином в территориальный орган Федеральной миграционной службы РФ не позднее чем за шесть месяцев до истечения срока действия разрешения на временное проживание. До

\footnotetext{
${ }^{22}$ См.: Смирникова Ю.Л. Валютно-правовой статус резидентов и нерезидентов // Внешнеторговое право. 2007. № 1.

${ }^{23}$ С3 РФ. 2002. № 30. Ст. 3032; 2013. № 52 (ч. 1). Ст. 6955. Новая редакция настоящего закона вступила в силу с 10 января 2014 г.
} 


\section{Системы стабилизации: финансовый контроль}

получения вида на жительство иностранный гражданин обязан прожить в РФ не менее одного года на основании разрешения на временное проживание. Вид на жительство выдается иностранному гражданину на пять лет. По окончании срока действия вида на жительство данный срок по заявлению иностранного гражданина, поданному в территориальный орган Федеральной миграционной службы РФ не позднее чем за два месяца до истечения срока действия имеющегося у него вида на жительство, может быть продлен на пять лет. Количество продлений срока действия вида на жительство не ограничено (п. 1-3 ст. 8). Основания для отказа в выдаче либо аннулирования вида на жительство содержатся в ст. 9 данного закона, причем перечень таких оснований является исчерпывающим. Очевидно, что именно эта и только эта категория иностранных граждан, находящихся на территории России, будет признана резидентами в значении, придаваемом валютным законодательством ${ }^{24}$.

Что же касается юридических лиц, то в основе их отнесения к категории резидентов и нерезидентов лежат общепризнанные в международном частном праве критерии инкорпорации и оседлости. Резидентами признаются юридические лица, созданные в соответствии с законодательством РФ (т.е. учрежденные в России). Создание юридического лица по российскому праву предполагает его регистрацию и внесение в Единый государственный реестр юридических лиц. Моментом государственной регистрации признается внесение регистрирующим органом соответствующей записи в государственный реестр. Государственная регистрация юридических лиц при их создании осуществляется регистрирующими органами по месту нахождения постоянно действующего исполнительного органа. Регистрация осуществляется в настоящее время Федеральной налоговой службой РФ в соответствии с требованиями Федерального закона «О государственной регистрации юридических лиц и индивидуальных предпринимателей» от 08 августа 2001 г. в ред. от 02 апреля 2014 г. $^{25}$ (ст. 13).

Нерезидентами признаются юридические лица, созданные в соответствии с законодательством иностранных государств и имеющие местонахождение за пределами территории РФ. В международном частном праве под местонахождением юридического лица имеется в виду расположение его управленческих органов.

\footnotetext{
${ }^{24} \mathrm{O}$ валютной правосубъектности особой категории физических лиц, а именно физических лиц - индивидуальных предпринимателей см.: Пыхтин С. Валютный статус индивидуального предпринимателя // Хозяйство и право. 2006. № 10.

${ }^{25}$ С3 РФ. 2001. № 33 (ч. 1). Ст. 3431; 2014. № 14. Ст. 1551. Новая редакция настоящего закона вступает в силу с 30 сентября 2014 г.
}

Таким образом, при определении круга физических лиц-резидентов как субъектов валютных отношений принимаются во внимание критерии гражданства и постоянного местожительства (известного в МЧП как домицилий). В отношении же юридических лиц при определении их статуса резидентства используются критерии инкорпорации и оседлости.

Рассмотрев специфику субъектов валютных отношений, остановимся на характеристике их объекта. Именно объект определяет особенности тех отношений между субъектами, которые мы называем «валютными». В самой общей форме особенность валютных отношений состоит в том, что их объектом всегда являются валюта $^{26}$ и ценные бумаги. Ни драгоценные металлы, ни драгоценные камни не квалифицируются как объекты валютного регулирования. Закон относит к числу объектов валютных отношений следующие категории:

\section{1) валюта РФ:}

- денежных знаки в виде банкнот и монеты Банка России, находящиеся в обращении в качестве законного средства наличного платежа на территории РФ, а также изымаемые либо изъятые из обращения, но подлежащие обмену указанные денежные знаки;

- средства на банковских счетах и в банковских вкладах;

\section{2) иностранная валюта:}

- денежные знаки в виде банкнот, казначейских билетов, монеты, находящиеся в обращении и являющиеся законным средством наличного платежа на территории соответствующего иностранного государства (группы иностранных государств), а также изымаемые либо изъятые из обращения, но подлежащие обмену указанные денежные знаки;

- средства на банковских счетах и в банковских вкладах в денежных единицах иностранных государств и международных денежных или расчетных единицах ${ }^{27}$;

\section{3) внутренние ценные бумаги:}

- эмиссионные ценные бумаги, номинальная стоимость которых указана в валюте РФ и выпуск которых зарегистрирован в РФ;

\footnotetext{
${ }^{26}$ См.: Ражков Р.А. Безналичная иностранная валюта как объект гражданского права // Банковское право. 2006. № 2. С. 55-57. По мнению автора, законодатель в одном термине «иностранная валюта» объединил два вида имущества: вещи (наличная иностранная валюта) и права требования к банку (безналичная иностранная валюта). Аналогичным образом законодатель поступил применительно и к национальной валюте (с. 55).

${ }^{27}$ См.: Степанченко А.В. К вопросу о залоге безналичной иностранной валюты // Банковское право. 2013. № 5.
} 


\section{Право и политика 5 (173) • 2014}

- $\quad$ иные ценные бумаги, удостоверяющие право на получение валюты РФ, выпущенные на территории РФ;

4) внешние ценные бумаги - ценные бумаги, в том числе в бездокументарной форме, не относящиеся к внутренним ценным бумагам ${ }^{28}$;

5) валютные ценности - иностранная валюта и внешние ценные бумаги (п. 1(1)-1(5) ст. 1).

\section{2) Понятие и виды валютных операций банков: общая характеристика}

Среди всех видов банковских операций валютные операции занимают особое место. Это связано с тем фактором, что содержательный аспект таких операций (будь то расчетные, гарантийные, вексельные и иные операции) неизбежно испытывает влияние валютного регулирования, приводящего в конечном итоге к удвоению структуры банковской операции: с одной стороны, по содержанию она остается чисто банковской операцией (например, кредитовый перевод; выдача банковской гарантии; акцепт векселя), а с другой стороны, по форме она приобретает характер валютной операции (кредитовый перевод иностранной валюты с банковского счета клиента-резидента в уполномоченном банке на его счет в банке-нерезиденте за рубежом; выдача банковской гарантии в качестве банка-гаранта в пользу бенефициара-нерезидента в иностранной валюте; акцепт векселя, выставленного трассантом-нерезидентом в иностранной валюте).

Валютные операции являются важнейшей составляющей валютных отношений. Наиболее общая характеристика валютных операций отражает тот факт, что такие операции всегда связаны с движением валютных ценностей и иных объектов валютных отношений ${ }^{29}$. Более детальное определение валютных операций может быть дано в следующей формулировке. Валютные операции - это комплекс действий резидентов и нерезидентов, совершаемых с валютой и ценными бумагами, как правило, в форме различного рода сделок, существенной чертой которых выступает движение валюты и ценных бумаг в виде перехода права собственности на них и/или их физического

\footnotetext{
${ }^{28}$ См.: Зоркольцев Р.Д. Вексель в иностранной валюте: возможно ли свободное обращение среди резидентов? // Банковское дело. 2012. № 5; Зоркольцев Р. Обращение векселей в иностранной валюте среди резидентов // Хозяйство и право. 2012. № 6.

${ }^{29}$ См.: Балабанов И.Т. Валютные операции. М., 1994. С. 16; Ceливановский А. Валютная операция - проблемы законодательного определения // Хозяйство и право. 2002. № 11. С. 49.
}

перемещения. Можно выделить три основания классификации валютных операций - по содержанию, по форме и по субъектному составу. По содержанию (по существу) можно выделить следующие виды валютных операций:

1) приобретение резидентом у резидента и отчуждение резидентом в пользу резидента валютных ценностей на законных основаниях, а также использование валютных ценностей в качестве средства платежа;

2) приобретение резидентом у нерезидента либо нерезидентом у резидента и отчуждение резидентом в пользу нерезидента либо нерезидентом в пользу резидента валютных ценностей, валюты РФ и внутренних ценных бумаг на законных основаниях, а также использование валютных ценностей, валюты РФ и внутренних ценных бумаг в качестве средства платежа;

3) приобретение нерезидентом у нерезидента и отчуждение нерезидентом в пользу нерезидента валютных ценностей, валюты РФ и внутренних ценных бумаг на законных основаниях, а также использование валютных ценностей, валюты РФ и внутренних ценных бумаг в качестве средства платежа;

4) ввоз в РФ и вывоз из РФ валютных ценностей, валюты РФ и внутренних ценных бумаг;

5) перевод иностранной валюты, валюты РФ, внутренних и внешних ценных бумаг со счета, открытого за пределами территории РФ, на счет того же лица, открытый на территории РФ, и со счета, открытого на территории РФ, на счет того же лица, открытый за пределами территории РФ;

6) перевод нерезидентом валюты РФ, внутренних и внешних ценных бумаг со счета (с раздела счета), открытого на территории РФ, на счет (раздел счета) того же лица, открытый на территории РФ;

7) перевод валюты РФ со счета резидента, открытого за пределами территории РФ, на счет другого резидента, открытый на территории РФ, и со счета резидента, открытого на территории РФ, на счет другого резидента, открытый за пределами территории РФ;

8) перевод валюты РФ со счета резидента, открытого за пределами территории РФ, на счет другого резидента, открытый за пределами территории РФ;

9) перевод валюты РФ со счета резидента, открытого за пределами территории РФ, на счет того же резидента, открытый за пределами территории РФ (п. 1(9) ст. 1 Закона).

По форме (по порядку осуществления) в теории валютного права среди всех разновидностей существующих валютных операций выделяется их обособленная группа - валютные операции движения ка- 


\section{Системы стабилизации: финансовый контроль}

питала между резидентами и нерезидентами. В ранее действовавшем валютном законодательстве России по этому основанию классификации все операции четко разделялись на две группы: текущие валютные операции и валютные операции, связанные с движением капитала. Необходимость именно такой классификации объяснялась существенным различием правового режима осуществления в отношении каждой группы: текущие валютные операции осуществлялись резидентами без ограничений, а операции, связанные с движением капитала, требовали получения лицензии (разрешения) Банка России на совершение такой операции. В предыдущей редакции нового Закона жесткая классификация валютных операций на текущие и связанные с движением капитала отсутствовала (Закон даже не употреблял термина «текущая валютная операция»), однако особая группа валютных операций движения капитала все-таки была выделена в Законе. Это объяснялось тем обстоятельством, что Закон устанавливал отдельный правовой режим осуществления валютных операций движения капитала, который определялся Правительством РФ и Банком России, однако данная разновидность валютных операций просуществовала до 01 января 2007 г.

По субъектному составу (по характеру участвующих в валютной операции субъектов) все разновидности валютных операций можно разделить на три категории: валютные операции между резидентами и нерезидентами; валютные операции между резидентами; валютные операции между нерезидентами ${ }^{30}$. Остановимся на их правовом регулировании более подробно.

1) Валютные операции между резидентами и нерезидентами. Валютные операции между резидентами и нерезидентами осуществляются без ограничений, за исключением валютных операций по купле-продаже иностранной валюты и чеков (в том числе дорожных чеков), номинальная стоимость которых указана в иностранной валюте. В отношении таких операций устанавливаются ограничения в целях предотвращения существенного сокращения золотовалютных резервов, резких колебаний курса валюты РФ, а также для поддержания устойчивости платежного баланса. Указанные ограничения носят недискримина-

\footnotetext{
${ }^{30}$ Валютное право использует два термина - валютная операция и валютная сделка. Очевидно, что термин «валютная операция» несет публично-правовой смысл, а термин «валютная сделка» частноправовой. Тем не менее, их взаимосвязь не представляется столь прямолинейной. См.: Ражков Р.А. «Валютные операции» и «валютные сделки»: проблемы соотношения дефиниций // Банковское право. 2006. № 3.
}

ционный характер и отменяются органами валютного регулирования по мере устранения обстоятельств, вызвавших их установление (ст. 6). Следует отметить, что установление требования об идентификации личности при купле-продаже физическими лицами наличной иностранной валюты и чеков (в том числе дорожных чеков), номинальная стоимость которых указана в иностранной валюте, не допускается, за исключением случаев, предусмотренных федеральными законами.

К числу таких законов относится Федеральный закон «О противодействии легализации (отмыванию) доходов, полученных преступным путем, и финансированию терроризма» от 07 августа 2001 г. в ред. от 28 декабря 2013 г. $^{31}$, согласно которому организации, осуществляющие операции с денежными средствами (в том числе покупку или продажу наличной иностранной валюты физическим лицом), обязаны идентифицировать физическое лицо - клиента или выгодоприобретателя. При осуществлении физическим лицом операции по покупке или продаже наличной иностранной валюты на сумму, не превышающую 600000 рублей либо не превышающую сумму в иностранной валюте, эквивалентную 600000 рублей, идентификация клиента - физического лица, установление и идентификация выгодоприобретателя не проводятся (п. 1 ст. 6; п. 1(2) ст. 7). Сведения, идентифицирующие личность, могут быть внесены в документы, оформляемые при куплепродаже наличной иностранной валюты и чеков по просьбе самого физического лица (п. 2 ст. 11 Закона).

2) Валютные операции между резидентами. Ocновной постулат правового регулирования валютных операций между резидентами заключается в том, что такие операции запрещены Законом ${ }^{32}$ (п. 1 ст. 9). Вместе с тем из общего правила есть целый ряд исключений, который и по смыслу, и по содержанию представляет собой не что иное, как перечень разрешенных на законодательном уровне валютных операций между резидентами. Их можно классифицировать по нескольким категориям.

а) Валютные операции юридических и физических лиц-резидентов:

- операции, связанные с расчетами в магазинах беспошлинной торговли, а также с расчетами при реализации товаров и оказании услуг пассажирам в пути следования транспортных средств при международных перевозках;

\footnotetext{
${ }^{31}$ СЗ РФ. 2001. № 33 (ч. 1). Ст. 3418; 2013. № 52 (ч. 1). Ст. 6968. Новая редакция настоящего закон вступила в силу с 30 декабря 2013 г.

${ }^{32}$ См.: Сливкин И.В. Валютные ограничения на использование иностранной валюты в качестве средства платежа по законодательству РФ // Закон. 2008. № 8.
} 
DOI: $10.7256 / 1811-9018.2014 .5 .11920$

При цитировании этой статьи сноска на dоі обязательна

\section{Право и политика $5(173) \cdot 2014$}

- операции между комиссионерами (агентами, поверенными) и комитентами (принципалами, доверителями) при оказании комиссионерами (агентами, поверенными) услуг, связанных с заключением и исполнением договоров с нерезидентами о передаче товаров, выполнении работ, об оказании услуг, о передаче информации и результатов интеллектуальной деятельности, в том числе исключительных прав на них, включая операции по возврату комитентам (принципалам, доверителям) денежных сумм (иного имущества);

- операции по договорам транспортной экспедиции, перевозки и фрахтования (чартера) при оказании экспедитором, перевозчиком и фрахтовщиком услуг, связанных с перевозкой вывозимого из РФ или ввозимого в РФ груза, транзитной перевозкой груза по территории РФ, а также по договорам страхования указанных грузов;

- $\quad$ операции с внешними ценными бумагами, осуществляемые на организованных торгах, при условии учета прав на такие ценные бумаги в депозитариях, созданных в соответствии с законодательством РФ;

- операции с внешними ценными бумагами при условии учета прав на такие ценные бумаги в депозитариях, созданных в соответствии с законодательством РФ, и осуществления расчетов в валюте РФ;

- $\quad$ операции, связанные с осуществлением обязательных платежей (налогов, сборов и других платежей) в федеральный бюджет, бюджет субъекта РФ, местный бюджет в иностранной валюте;

- операции, связанные с выплатами по внешним ценным бумагам (в том числе закладным), за исключением векселей;

- $\quad$ операций при оплате и (или) возмещении расходов физического лица, связанных со служебной командировкой за пределы территории РФ, а также операции при погашении неизрасходованного аванса, выданного в связи со служебной командировкой;

- операции, связанные с расчетами и переводами иностранной валюты при исполнении бюджетов бюджетной системы РФ в соответствии с бюджетным законодательством РФ;

- $\quad$ операции, предусматривающие расчеты и переводы иностранной валюты для осуществления деятельности дипломатических представительств, консульских учреждений РФ и иных официальных представительств РФ, находящихся за пределами территории РФ, а также постоянных представительств РФ при межгосударственных или межправительственных организациях;
- переводы физическим лицом-резидентом иностранной валюты из РФ в пользу иных физических лиц-резидентов на их счета, открытые в банках, расположенных за пределами территории РФ, в суммах, не превышающих в течение одного операционного дня через один уполномоченный банк суммы, равной в эквиваленте 5000 долларов США по официальному курсу, установленному Банком России на дату списания денежных средств со счета физического лица-резидента;

- переводы физическим лицом-резидентом иностранной валюты в РФ со счетов, открытых в банках, расположенных за пределами территории РФ, в пользу иных физических лиц-резидентов на их счета в уполномоченных банках;

- операции по оплате и (или) возмещению расходов, связанных со служебными поездками за пределы территории РФ работников, постоянная работа которых осуществляется в пути или имеет разъездной характер;

- $\quad$ операции, указанные выше, совершаемые доверительными управляющими;

- операции, связанные с расчетами между транспортными организациями и находящимися за пределами территории РФ физическими лицами, а также филиалами, представительствами и иными подразделениями юридических лиц, созданных в соответствии с законодательством РФ, по договорам перевозки пассажиров;

- переводы физическими лицами-резидентами иностранной валюты со своих счетов, открытых в уполномоченных банках, в пользу иных физических лиц-резидентов, являющихся их супругами или близкими родственниками (родственниками по прямой восходящей и нисходящей линии (родителями и детьми, дедушкой, бабушкой и внуками), полнородными и неполнородными (имеющими общих отца или мать) братьями и сестрами, усыновителями и усыновленными), на счета указанных лиц, открытые в уполномоченных банках либо в банках, расположенных за пределами территории $Р \Phi^{33}$;

\footnotetext{
${ }^{33}$ В последнем случае согласно п. 1 Указания ЦБ РФ № 1868-У «О представлении физическими лицами-резидентами уполномоченным банкам документов, связанных с проведением отдельных валютных операций» от 20 июля 2007 г. вышеуказанные физические лица представляют уполномоченному банку, через который осуществляются валютные операции по переводу иностранной валюты, документы, подтверждающие, что физические лица являются супругами или близкими родственниками (Вестник Банка России. 2007. № 46).
} 


\section{Системы стабилизации: финансовый контроль}

- переводы иностранной валюты на счета дипломатических представительств, консульских учреждений РФ и иных официальных представительств РФ, находящихся за пределами территории России, а также на счета постоянных представительств РФ при межгосударственных или межправительственных организациях со счетов, открытых в уполномоченных банках федеральными органами исполнительной власти, осуществляющими функции, связанные с их деятельностью за пределами территории РФ через своих представителей или представительства, и организациями, имеющими на основании федерального закона право по использованию счетов указанных официальных представительств и постоянных представительств РФ, для выплаты заработной платы и иных выплат, связанных с содержанием своих представителей или сотрудников своих представительств за пределами территории России, а также для оплаты и (или) возмещения расходов, связанных с их командированием;

- переводы иностранной валюты, переведенной в соответствии с вышеуказанным пунктом на счета, открытые в уполномоченных банках соответствующими федеральными органами исполнительной власти и организациями, со счетов дипломатических представительств, консульских учреждений РФ и иных официальных представительств РФ, находящихся за пределами территории России, а также со счетов постоянных представительств РФ при межгосударственных или межправительственных организациях;

- операции, связанные с внесением и возвратом индивидуального и (или) коллективного клирингового обеспечения в соответствии с Федеральным законом «О клиринге и клиринговой деятельности» от 07 февраля 2011 г. в ред. от 12 марта 2014 г. ${ }^{34}$;

- операции, связанные с расчетами по итогам клиринга, осуществляемого в соответствии с Федеральным законом «О клиринге и клиринговой деятельности»;

- операции между комиссионерами (агентами, поверенными) и комитентами (принципалами, доверителями) при оказании комиссионерами (агентами, поверенными) услуг, связанных с заключением и исполнением договоров, обязательства по которым подлежат исполнению по итогам клиринга, осу-

${ }^{34}$ С3 РФ. 2011. № 7. Ст. 904; 2014. № 11. Ст. 1098. Новая редакция настоящего закона вступила в силу с 12 марта 2014 г. ществляемого в соответствии с Федеральным законом «О клиринге и клиринговой деятельности», в том числе возвратом комитентам (принципалам, доверителям) денежных сумм (иного имущества);

- операции, связанные с исполнением и (или) прекращением договора, являющегося производным финансовым инструментом, при условии, что одной из сторон по такому договору является уполномоченный банк или профессиональный участник рынка ценных бумаг (п. 1(2)-1(23) ст. 9 Закона).

б) Валютные операции физическихлиц-резидентов:

- передача физическим лицом-резидентом валютных ценностей в дар РФ, субъекту РФ или муниципальному образованию;

- $\quad$ дарение валютных ценностей супругу и близким родственникам;

- $\quad$ завещание валютных ценностей или получение их по праву наследования;

- приобретение и отчуждение в целях коллекционирования единичных денежных знаков и монет;

- перевод физическим лицом-резидентом из РФ и получение в РФ физическим лицом-резидентом перевода без открытия банковских счетов, осуществляемые в установленном порядке, который может предусматривать только ограничение суммы перевода, а также почтового перевода;

- покупка у уполномоченного банка или продажа уполномоченному банку физическим лицом-резидентом наличной иностранной валюты, обмен, замена денежных знаков иностранного государства (группы иностранных государств), а также прием для направления на инкассо в банки за пределами территории РФ наличной иностранной валюты;

- $\quad$ расчеты физических лиц-резидентов в иностранной валюте в магазинах беспошлинной торговли, а также при реализации товаров и оказании услуг физическим лицам-резидентам в пути следования транспортных средств при международных перевозках;

- $\quad$ расчеты, осуществляемые физическими лицамирезидентами, по договорам перевозки пассажиров с транспортными организациями, если физические лица-резиденты находятся за пределами территории РФ;

- перевод без открытия банковского счета физическим лицом-резидентом в пользу нерезидента на территории РФ, получения физическим лицомрезидентом перевода без открытия банковского счета на территории РФ от нерезидента, осуществляемых в установленном Банком России порядке, 


\section{Право и политика $5(173) \cdot 2014$}

который может предусматривать соответственно только ограничение суммы перевода и суммы получения перевода (п. 3(1)-(9) ст. 14 Закона).

в) Валютные операции по сделкам между уполномоченными банками,

совершаемые ими от своего имени и за свой счет:

- $\quad$ операции, отнесенные к банковским операциям;

- $\quad$ операции, связанные с исполнением обязательств по выплате иностранной валюты в соответствии с договорами поручительства и договорами залога, исполнение регрессных требований поручителей;

- $\quad$ операции, связанные с приобретением у третьих лиц- уполномоченных банков, а также с уступкой третьим лицам-уполномоченным банкам за иностранную валюту требований исполнения обязательств в денежной форме;

- $\quad$ операции, связанные с расчетами в иностранной валюте по договорам финансовой аренды (договорам лизинга);

- $\quad$ операции с внешними ценными бумагами;

- $\quad$ операции, связанные с осуществлением платежей в иностранной валюте по операциям с внутренними ценными бумагами и внешними ценными бумагами;

- операции, связанные с привлечением денежных средств в иностранной валюте в виде кредитов;

- $\quad$ операции, связанные с доверительным управлением денежными средствами;

- операции, связанные с уплатой комиссионного вознаграждения (оплатой услуг уполномоченного банка) по вышеуказанным операциям.

- $\quad$ Валютные операции, не включенные в данный перечень, осуществляются уполномоченными банками в порядке, установленном для юридических лиц-резидентов, не являющихся уполномоченными банками (п. 1-2 Указания ЦБ РФ № 1425-У «О порядке осуществления валютных операций по сделкам между уполномоченными банками» от 28 апреля $2004 \Gamma^{35}$ )

- 2) Валютные операции между резидентами и уполномоченными банками, связанные:

- с получением и возвратом кредитов и займов, уплатой сумм процентов и штрафных санкций по соответствующим договорам;

- $\quad$ в внесением денежных средств резидентов на банковские счета (в банковские вклады) (до востребования и на определенный срок) и получением денежных средств резидентов с банковских счетов

${ }^{35}$ Вестник Банка России. 2004. № 33. (банковских вкладов) (до востребования и на определенный срок);

- $\quad$ с банковскими гарантиями, а также с исполнением резидентами обязательств по договорам поручительства и залога;

- $\quad$ с приобретением резидентами у уполномоченных банков векселей, выписанных этими или другими уполномоченными банками, предъявлением их к платежу, получением по ним платежа, в том числе в порядке регресса, взысканием по ним штрафных санкций, а также с отчуждением резидентами указанных векселей уполномоченным банкам в порядке, установленном Федеральным законом «О переводном и простом векселе» от 11 марта 1997 г. ${ }^{36}$;

- $\quad$ с куплей-продажей физическими лицами наличной и безналичной иностранной валюты и чеков (в том числе дорожных чеков), номинальная стоимость которых указана в иностранной валюте, за валюту РФ и иностранную валюту, а также с обменом, заменой денежных знаков иностранного государства (группы иностранных государств), приемом для направления на инкассо в банки за пределами территории РФ наличной иностранной валюты и чеков (в том числе дорожных чеков), номинальная стоимость которых указана в иностранной валюте, не для целей осуществления физическими лицами предпринимательской деятельности;

- с уплатой уполномоченным банкам комиссионного вознаграждения;

- с иными валютными операциями, отнесенными к банковским операциям (п. 3(1)-(7) ст. 9 Закона).

- Существенная детализация некоторых из вышеуказанных валютных операций была проведена в отдельном нормативно-правовом акте Банка России, а именно в Инструкции ЦБ РФ № 136-И «О порядке осуществления уполномоченными банками (филиалами) отдельных видов банковских операций с наличной иностранной валютой и операций с чеками (в том числе дорожными чеками), номинальная стоимость которых указана в иностранной валюте, с участием физических лиц» от 16 сентября 2010 г. ${ }^{37}$ Настоящая инструкция содержит Главу 3 «Операции с наличной иностранной валютой и чеками», которая различает 21 вид таких операций, в число которых включаются:

\footnotetext{
${ }^{36}$ СЗ РФ. 1997. № 11. Ст. 1238.

${ }^{37}$ Вестник Банка России. 2010. № 55. Настоящая инструкция вступила в силу с 01 ноября 2010 г.
} 
- покупка наличной иностранной валюты за наличную валюту РФ;

- $\quad$ продажа наличной иностранной валюты за наличную валюту РФ;

- продажа наличной иностранной валюты одного иностранного государства (группы иностранных государств) за наличную иностранную валюту другого иностранного государства (группы иностранных государств) (конверсия);

- $\quad$ размен денежного знака (денежных знаков) иностранного государства (группы иностранных государств) на денежные знаки (денежный знак) того же иностранного государства (группы иностранных государств);

- покупка чеков за наличную валюту РФ;

- покупка чеков за наличную иностранную валюту;

- продажа чеков за наличную валюту РФ;

- продажа чеков за наличную иностранную валюту;

- $\quad$ прием денежных знаков иностранных государств (группы иностранных государств), чеков для направления на инкассо;

- прием наличной иностранной валюты для зачисления на банковские счета физических лиц с использованием платежных карт;

- выдача наличной иностранной валюты с банковских счетов физических лиц с использованием платежных карт;

- $\quad$ покупка чеков с зачислением денежных средств на банковские счета, счета по вкладу физических лиц в иностранной валюте;

- $\quad$ покупка чеков с зачислением денежных средств на банковские счета, счета по вкладу физических лиц в валюте РФ;

- $\quad$ продажа чеков за счет денежных средств на банковских счетах, счетах по вкладу физических лиц в иностранной валюте;

- продажа чеков за счет денежных средств на банковских счетах, счетах по вкладу физических лиц в валюте РФ;

- прием наличной иностранной валюты при осуществлении операций по переводу денежных средств из РФ по поручению физических лиц без открытия банковских счетов;

- выдача наличной иностранной валюты при осуществлении операций по переводу денежных средств в РФ без открытия банковских счетов в пользу физических лиц;

- прием наличной иностранной валюты для зачисления на банковские счета, счета по вкладу физических лиц в иностранной валюте;
- прием наличной иностранной валюты для зачисления на банковские счета, счета по вкладу физических лиц в валюте РФ;

- выдача наличной иностранной валюты с банковских счетов, счетов по вкладу физических лиц в иностранной валюте;

- $\quad$ выдача наличной иностранной валюты с банковских счетов, счетов по вкладу физических лиц в валюте РФ.

- Уполномоченный банк (филиал уполномоченного банка) может осуществлять все или некоторые операции с наличной иностранной валютой и чеками из числа предусмотренных выше. Перечень осуществляемых операций с наличной иностранной валютой и чеками устанавливается уполномоченным банком (филиалом) в целом по уполномоченному банку (филиалу), а также по каждому внутреннему структурному подразделению уполномоченного банка (филиала) исходя из перечня делегированных этому подразделению операций в соответствии с требованиями Инструкции ЦБ РФ N 135-И «О порядке принятия Банком России решения о государственной регистрации кредитных организаций и выдаче лицензий на осуществление банковских операций» от 02 апреля 2010 г. в ред. от 26 ноября 2013 г. $^{38}$

- Уполномоченный банк (филиал) определяет перечень иностранных валют, операции с которыми осуществляются уполномоченным банком (филиалом). Уполномоченный банк (филиал) самостоятельно решает вопрос о необходимости работы с монетой иностранных государств (группы иностранных государств) при осуществлении операций с наличной иностранной валютой и чеками. В случае, если уполномоченным банком (филиалом) принято решение об отсутствии необходимости работы с монетой иностранных государств (группы иностранных государств), выплата физическим лицам при осуществлении операций с наличной иностранной валютой и чеками суммы менее номинала минимального денежного знака иностранного государства (группы иностранных государств) в виде банкноты осуществляется в валюте РФ по курсу, установленному уполномоченным банком (филиалом), если иное не предусмотрено договором при осуществлении операций по банковскому счету, счету по вкладу физического лица (п. 1.1. - 1.3. Инструкции ЦБ РФ N 136-И).

\footnotetext{
${ }^{38}$ Вестник Банка России. 2010. № 23; 2014. № 5-6. Новая редакция настоящей инструкции вступила в силу с 31 января 2014 г.
} 


\section{Право и политика 5 (173) • 2014}

3) Валютные операции между нерезидентами. Нерезиденты вправе без ограничений осуществлять между собой переводы иностранной валюты и валюты РФ со счетов (с вкладов) в банках за пределами территории РФ на банковские счета (в банковские вклады) в уполномоченных банках или банковских счетов (банковских вкладов) в уполномоченных банках на счета (во вклады) в банках за пределами территории РФ или в уполномоченных банках. Нерезиденты вправе без ограничений осуществлять между собой на территории РФ переводы иностранной валюты и валюты РФ без открытия банковских счетов, а также осуществлять переводы иностранной валюты и валюты РФ без открытия банковских счетов с территории РФ и получать на территории РФ переводы иностранной валюты и валюты РФ без открытия банковских счетов (п. 1 ст. 10 Закона).

Нерезиденты вправе осуществлять между собой валютные операции с внутренними ценными бумагами на территории РФ с учетом требований, установленных антимонопольным законодательством и законодательством о рынке ценных бумаг. Валютные операции между нерезидентами на территории РФ в валюте РФ осуществляются через банковские счета (банковские вклады), открытые на территории РФ. Валютные операции между нерезидентами на территории РФ в валюте РФ осуществляются через банковские счета (банковские вклады), открытые на территории РФ в порядке, предусмотренном ст. 13 Закона, за исключением случаев перевода иностранной валюты и валюты РФ без открытия банковских счетов (п. 2-3 ст. 10 Закона).

Нерезиденты на территории РФ вправе открывать банковские счета (банковские вклады) в иностранной валюте и валюте РФ только в уполномоченных банках. Нерезиденты имеют право без ограничений перечислять иностранную валюту и валюту РФ со своих банковских счетов (с банковских вкладов) в банках за пределами территории РФ на свои банковские счета (в банковские вклады) в уполномоченных банках. Нерезиденты имеют право без ограничений перечислять иностранную валюту и валюту РФ со своих банковских счетов (с банковских вкладов) в уполномоченных банках на свои счета (во вклады) в банках за пределами территории РФ (п. 1-4 ст. 13 Закона) $)^{39}$.

\footnotetext{
${ }^{39}$ Порядок совершения резидентами и нерезидентами валютных операций регулируется Инструкцией ЦБ РФ № 138-И «О порядке представления резидентами и нерезидентами уполномоченным банкам документов и информации, связанных с проведением валютных операций, порядке оформления паспортов сделок, а также порядке учета уполномоченными банками валютных операций и контроля за их проведением» от 04 июня 2012 г. в ред. от 14 июня 2013 г. (Вестник Банка России. 2012. № 48-49; 2013. № 44).
}

\section{3) Открытие и ведение счетов в валюте РФ и иностранной валюте резидентами \\ и нерезидентами в уполномоченных банках на территории России, а также счетов в валюте РФ и иностранной валюте за границей}

Резиденты и нерезиденты (физические и юридические лица, а также физические лица - индивидуальные предприниматели) вправе открывать банковские счета в валюте РФ и иностранной валюте в уполномоченных банках на территории России. Кроме того, резиденты (физические и юридические лица, а также физические лица - индивидуальные предприниматели) вправе открывать счета в иностранной валюте в банках, расположенных за пределами территории России. Правовой режим таких счетов установлен в Законе и в нормативно-правовых актах Банка России. Определяющий элемент правового регулирования применительно к рассматриваемому вопросу заключается в требовании осуществления всех валютных операций между резидентами и нерезидентами, связанных с безналичными расчетами, через банковские счета.

a) Правовой режим счетов физических лицрезидентов в банках, расположенных за пределами территории России

Физические лица-резиденты, за исключением случаев, предусмотренных Федеральным законом «О запрете отдельным категориям лиц открывать и иметь счета (вклады), хранить наличные денежные средства и ценности в иностранных банках, расположенных за пределами территории РФ, владеть и (или) пользоваться иностранными финансовыми инструментами» от 7 мая 2013 г. ${ }^{40}$, открывают без ограничений счета (вклады) в иностранной валюте и валюте РФ в банках, расположенных за пределами территории РФ. Резиденты обязаны уведомлять налоговые органы по месту своего учета об открытии (закрытии) счетов (вкладов) и об изменении реквизитов счетов (вкладов) не позднее одного месяца со дня соответственно открытия (закрытия) или изменения реквизитов таких счетов (вкладов) в банках, расположенных за пределами территории РФ (п. 1-2 ст. 12). Положение об уведомительном порядке открытия физическим лицом-резидентом счета в банке за границей вступило в силу с 01 января 2007 г., и с этого же момента утратил силу регистрационный порядок открытия таким лицом банковского счета за границей.

\footnotetext{
${ }^{40}$ СЗ РФ. 2013. № 19. Ст. 2306. Настоящий закон вступил в силу
} с 19 мая 2013 г. 


\section{Системы стабилизации: финансовый контроль}

Физические лица-резиденты вправе переводить на свои счета (во вклады), открытые в банках за пределами территории РФ, средства со своих счетов (вкладов) в уполномоченных банках или других своих счетов (вкладов), открытых в банках за пределами территории РФ. Переводы резидентами средств на свои счета (во вклады), открытые в банках за пределами территории РФ, со своих счетов (вкладов) в уполномоченных банках осуществляются при предъявлении уполномоченному банку при первом переводе уведомления налогового органа по месту учета резидента об открытии счета (вклада) с отметкой о принятии указанного уведомления (п. 4 ст. 12 Закона). Следовательно, общий вывод в отношении правового режима счетов физических лиц-резидентов в банках за пределами территории России заключается в том, что такие счета с 01 января 2007 г. открываются в уведомительном порядке. Физические лица-резиденты вправе без ограничений осуществлять валютные операции, не связанные с передачей имущества и оказанием услуг на территории РФ, с использованием средств, зачисленных на счета (во вклады), открытые в банках за пределами территории РФ (п. 6 ст. 12).

б) Правовой режим счетов юридических лицрезидентов в банках, расположенных за пределами территории России

Юридические лица-резиденты открывают без ограничений счета (вклады) в иностранной валюте и валюте РФ в банках, расположенных за пределами территории РФ. Резиденты обязаны уведомлять налоговые органы по месту своего учета об открытии (закрытии) счетов (вкладов) и об изменении реквизитов счетов (вкладов) не позднее одного месяца со дня соответственно открытия (закрытия) или изменения реквизитов таких счетов (вкладов) в банках, расположенных за пределами территории РФ (п. 1-2 ст. 12) $)^{41}$ Юридические лица-резиденты представляют налоговым органам по месту своего учета отчеты о движении средств по счетам (вкладам) в банках за пределами территории РФ с подтверждающими банковскими документами в порядке, устанавливаемом Правительством РФ по согласованию с Банком России (п. 7 ст. 12). Юридические лица-резиденты вправе без ограничений осуществлять валютные операции со средствами, зачисленными в соответствии с Законом на счета (во вклады), открытые в банках за пределами территории РФ, за исключением валютных операций между резидентами (п. 6 ст. 12). Со средствами, зачисленными в соответствии с Законом на

${ }^{41}$ Данная норма начала действовать с 01 января 2007 г. счета (во вклады), открытые в банках за пределами территории РФ, между резидентами без ограничений осуществляются следующие валютные операции:

1) операции по выплате заработной платы сотрудникам дипломатических представительств, консульских учреждений РФ и иных официальных представительств РФ, находящихся за пределами территории РФ, а также постоянных представительств РФ при межгосударственных или межправительственных организациях;

2) операции по выплате заработной платы сотрудникам представительства юридического лица-резидента, находящегося за пределами территории РФ;

3) операции по оплате и (или) возмещению расходов, связанных с командированием таких сотрудников на территорию страны местонахождения вышеуказанных представительств, учреждений и организаций и за ее пределы, за исключением территории РФ;

4) перевод валюты РФ со счета резидента, открытого за пределами территории РФ, на счет другого резидента, открытый на территории РФ, и со счета резидента, открытого на территории РФ, на счет другого резидента, открытый за пределами территории РФ;

5) перевод валюты РФ со счета резидента, открытого за пределами территории РФ, на счет другого резидента, открытый за пределами территории РФ;

6) операции, связанные с расчетами и переводами иностранной валюты при исполнении бюджетов бюджетной системы РФ в соответствии с бюджетным законодательством РФ;

7) операции, предусматривающие расчеты и переводы иностранной валюты для осуществления деятельности дипломатических представительств, консульских учреждений РФ и иных официальных представительств РФ, находящихся за пределами территории РФ, а также постоянных представительств РФ при межгосударственных или межправительственных организациях;

8) операции, связанные с расчетами между транспортными организациями и находящимися за пределами территории РФ физическими лицами, а также филиалами, представительствами и иными подразделениями юридических лиц, созданных в соответствии с законодательством РФ, по договорам перевозки пассажиров;

9) операции, связанные с переводами иностранной валюты на счета дипломатических представительств, консульских учреждений РФ и иных официальных представительств РФ, находящихся за пределами территории России, а также на счета постоянных пред- 
DOI: $10.7256 / 1811-9018.2014 .5 .11920$

При цитировании этой статьи сноска на dоі обязательна

\section{Право и политика $5(173) \cdot 2014$}

ставительств РФ при межгосударственных или межправительственных организациях со счетов, открытых в уполномоченных банках федеральными органами исполнительной власти, осуществляющими функции, связанные с их деятельностью за пределами территории РФ через своих представителей или представительства, и организациями, имеющими на основании федерального закона право по использованию счетов указанных официальных представительств и постоянных представительств РФ, для выплаты заработной платы и иных выплат, связанных с содержанием своих представителей или сотрудников своих представительств за пределами территории России, а также для оплаты и (или) возмещения расходов, связанных с их командированием;

10) операции, связанные с переводами иностранной валюты, переведенной в соответствии с вышеуказанным пунктом на счета, открытые в уполномоченных банках соответствующими федеральными органами исполнительной власти и организациями, со счетов дипломатических представительств, консульских учреждений РФ и иных официальных представительств РФ, находящихся за пределами территории России, а также со счетов постоянных представительств РФ при межгосударственных или межправительственных организациях;

11) операции, связанные с расчетами в иностранной валюте и валюте РФ между юридическими лицамирезидентами и находящимися за пределами территории России физическими лицами-резидентами, а также филиалами, представительствами и иными подразделениями юридических лиц, созданных в соответствии с законодательством РФ, и физическими лицами-нерезидентами по договорам перевозки пассажиров, а также расчеты с находящимися за пределами территории России физическими лицами-резидентами и физическими лицами-нерезидентами по договорам перевозки грузов, перевозимых физическими лицами для личных, семейных, домашних и иных нужд, не связанных с осуществлением предпринимательской деятельности;

12) операции, связанные с расчетами в наличной иностранной валюте, переведенной в соответствии с п. 1(18) ст. 9 Закона, дипломатических представительств, консульских учреждений РФ и иных официальных представительств РФ, находящихся за пределами территории России, а также постоянных представительств РФ при межгосударственных или межправительственных организациях без использования банковских счетов в уполномоченных банках с представителями или сотрудниками представительств федеральных органов исполнительной власти и организаций;
$13)$ операции, связанные с расчетами в наличной иностранной валюте без использования банковских счетов в уполномоченных банках юридических лиц-резидентов с находящимися за пределами территории России физическими лицами-резидентами 42 (п. 6.1. ст. 12 Закона).

Расчеты при осуществлении валютных операций производятся юридическими лицами-резидентами через банковские счета в уполномоченных банках, порядок открытия и ведения которых устанавливается Банком России, а также переводами электронных денежных средств. Расчеты при осуществлении валютных операций могут производиться юридическими лицамирезидентами через счета, открытые в банках за пределами территории РФ, за счет средств, зачисленных на эти счета в соответствии с Законом. Юридические лица-резиденты могут осуществлять без использования банковских счетов в уполномоченных банках расчеты с физическими лицами-нерезидентами в наличной валюте РФ по договорам розничной купли-продажи товаров, а также расчеты при оказании физическим лицам-нерезидентам на территории РФ транспортных, гостиничных и других услуг, оказываемых населению. Юридические лица-резиденты могут осуществлять без использования банковских счетов в уполномоченных банках расчеты с нерезидентами в наличной иностранной валюте и валюте РФ за обслуживание воздушных судов иностранных государств в аэропортах, судов иностранных государств в речных и морских портах, а также при оплате нерезидентами аэронавигационных, аэропортовых и портовых сборов на территории РФ.

Юридические лица-резиденты могут осуществлять без использования банковских счетов в уполномоченных банках расчеты в наличной иностранной валюте и наличной валюте РФ с нерезидентами за обслуживание воздушных судов таких юридических лиц в аэропортах иностранных государств, судов таких юридических лиц в речных и морских портах иностранных государств, иных транспортных средств таких юридических лиц во время их нахождения на территориях

\footnotetext{
${ }^{42}$ На счета резидентов, открытые в банках, расположенных на территориях иностранных государств, являющихся членами Организации экономического сотрудничества и развития (ОЭСР) или Группы разработки финансовых мер борьбы с отмыванием денег (ФАТФ), могут быть зачислены суммы кредитов и займов в иностранной валюте, полученные по кредитным договорам и договорам займа с организациями-нерезидентами, являющимися агентами правительств иностранных государств, а также по кредитным договорам и договорам займа, заключенным с резидентами государств - членов ОЭСР или ФАТФ на срок свыше двух лет (п. 5 ст. 12 Закона).
} 


\section{Системы стабилизации: финансовый контроль}

иностранных государств, а также при оплате такими юридическими лицами аэронавигационных, аэропортовых, портовых сборов и иных обязательных сборов на территориях иностранных государств, связанных с обеспечением деятельности таких юридических лиц.

Юридические лица-резиденты могут осуществлять без использования банковских счетов в уполномоченных банках расчеты в иностранной валюте и валюте РФ с находящимися за пределами территории РФ физическими лицами-резидентами, а также филиалами, представительствами и иными подразделениями юридических лиц, и физическими лицами-нерезидентами по договорам перевозки пассажиров, а также расчеты в иностранной валюте и валюте РФ с находящимися за пределами территории РФ физическими лицами-резидентами и физическими лицами-нерезидентами по договорам перевозки грузов, перевозимых физическими лицами для личных, семейных, домашних и иных нужд, не связанных с осуществлением предпринимательской деятельности.

Дипломатические представительства, консульские учреждения РФ и иные официальные представительства РФ, находящиеся за пределами территории РФ, а также постоянные представительства РФ при межгосударственных или межправительственных организациях могут осуществлять без использования банковских счетов в уполномоченных банках расчеты в наличной иностранной валюте, переведенной в соответствии с п. 1(18) ст. 9 Закона, с представителями или сотрудниками представительств указанных в п. 1(18) ст. 9 Закона федеральных органов исполнительной власти и организаций. Юридические лица-резиденты могут осуществлять без использования банковских счетов в уполномоченных банках расчеты в наличной иностранной валюте с находящимися за пределами территории РФ физическими лицами-резидентами по операциям в соответствии с п. 6.1 ст. 12 Закона (п. 2 ст. 14). Необходимо еще раз подчеркнуть, что на смену регистрационному порядку открытия юридическими лицамирезидентами счетов в банках-нерезидентах пришел уведомительный порядок с 01 января 2007 г.

\section{4) Ввоз и пересылка в Россию, вывоз и пересылка из России валютных ценностей, валюты РФ и внутренних ценных бумаг резидентами и нерезидентами}

Согласно ст. 15 Закона ввоз в РФ и вывоз из РФ иностранной валюты и (или) валюты РФ, а также дорожных чеков, внешних и (или) внутренних ценных бумаг в документарной форме осуществляются резидентами и нерезидентами без ограничений при соблюдении требований таможенного законодательства Таможенного союза в рамках Евразийского экономического сообщества (далее - ЕврАзЭС) и законодательства РФ о таможенном деле ${ }^{43}$. Решением Межгосударственного совета ЕврАзЭС № 51 от 05 июля 2010 г. был принят Договор о порядке перемещения физическими лицами наличных денежных средств и (или) денежных инструментов через таможенную границу Таможенного союза ${ }^{44}$. Договор определяет порядок перемещения физическими лицами наличных денежных средств и (или) денежных инструментов через таможенную границу Таможенного союза. Положения Договора не регулируют отношения, возникающие в связи с перемещением физическими лицами через таможенную границу Таможенного союза монет из драгоценных металлов, являющихся законным платежным средством (ст. 1). Для целей настоящего Договора используются следующие термины и их определения:

- «наличные денежные средства» - денежные знаки в виде банкнот и казначейских билетов, монет, за исключением монет из драгоценных металлов, находящиеся в обращении и являющиеся законным платежным средством в государствах - членах Таможенного союза или иностранных государствах (группе иностранных государств), включая изъятые либо изымаемые из обращения, но подлежащие обмену на находящиеся в обращении денежные знаки;

- «денежные инструменты» - дорожные чеки, векселя, чеки (банковские чеки), а также ценные бумаги в документарной форме, удостоверяющие обязательство эмитента (должника) по выплате денежных средств, в которых не указано лицо, которому осуществляется такая выплата (ст. 2).

Ввоз физическим лицом наличных денежных средств и (или) дорожных чеков на таможенную территорию Таможенного союза осуществляется без ограничений в следующем порядке:

- при единовременном ввозе наличных денежных средств и (или) дорожных чеков на общую сумму, равную либо не превышающую в эквиваленте 10000 долларов США, указан-

\footnotetext{
${ }^{43}$ Примером может служить Федеральный закон «О таможенном регулировании в РФ» от 27 ноября 2010 г. в ред. от 12 марта 2014 г. (СЗ РФ. 2010. № 48. Ст. 6252; 2014. № 11. Ст. 1098). Новая редакция настоящего закона вступит в силу с 01 июня 2014 г.

${ }^{44}$ Настоящий договор вступил в силу с 03 июня 2011 г. на территории государств - членов Таможенного союза ЕврАзЭС (России, Белоруссии и Казахстана).
} 
DOI: $10.7256 / 1811-9018.2014 .5 .11920$

При цитировании этой статьи сноска на dоі обязательна

\section{Право и политика $5(173) \cdot 2014$}

ные денежные средства и (или) дорожные чеки не подлежат таможенному декларированию в письменной форме;

- $\quad$ при единовременном ввозе наличных денежных средств и (или) дорожных чеков на общую сумму, превышающую в эквиваленте 10000 долларов США, указанные денежные средства и (или) дорожные чеки подлежат таможенному декларированию в письменной форме путем подачи пассажирской таможенной декларации на всю сумму ввозимых наличных денежных средств и (или) дорожных чеков.

Единовременный ввоз физическим лицом наличных денежных средств и (или) дорожных чеков на общую сумму, равную либо не превышающую в эквиваленте 10000 долларов США, может быть задекларирован в письменной форме по желанию физического лица. Ввоз физическим лицом денежных инструментов, за исключением дорожных чеков, осуществляется при условии таможенного декларирования в письменной форме путем подачи пассажирской таможенной декларации (ст. 3).

Вывоз физическим лицом наличных денежных средств и (или) дорожных чеков с таможенной территории Таможенного союза осуществляется без ограничений в следующем порядке:

- $\quad$ при единовременном вывозе наличных денежных средств и (или) дорожных чеков на общую сумму, равную либо не превышающую в эквиваленте 10000 долларов США, указанные денежные средства и (или) дорожные чеки не подлежат таможенному декларированию в письменной форме;

- $\quad$ при единовременном вывозе наличных денежных средств и (или) дорожных чеков на общую сумму, превышающую в эквиваленте 10000 долларов США, указанные денежные средства и (или) дорожные чеки подлежат таможенному декларированию в письменной форме путем подачи пассажирской таможенной декларации на всю сумму вывозимых наличных денежных средств и (или) дорожных чеков.

Единовременный вывоз физическим лицом наличных денежных средств и (или) дорожных чеков в общей сумме, равной либо не превышающей в эквиваленте $\mathbf{1 0}$ 000 долларов США, может быть задекларирован в письменной форме по желанию физического лица. Вывоз физическим лицом денежных инструментов, за исключением дорожных чеков, осуществляется при условии таможенного декларирования в письменной форме путем подачи пассажирской таможенной декларации (ст. 4).
В случаях ввоза на таможенную территорию Таможенного союза или вывоза с этой территории физическим лицом наличных денежных средств и (или) дорожных чеков перерасчет в доллары США осуществляется по курсу, установленному в соответствии с законодательством той Стороны, через государственную границу которой перемещаются такие наличные денежные средства и (или) дорожные чеки, на день подачи пассажирской таможенной декларации таможенному органу. При таможенном декларировании денежных инструментов, за исключением дорожных чеков, в пассажирской таможенной декларации указывается номинальная стоимость либо соответствующая сумма в валюте государства - члена Таможенного союза или иностранной валюте, право на получение которой удостоверяет денежный инструмент. В случае отсутствия номинальной стоимости и невозможности определить сумму в валюте государства - члена Таможенного союза или иностранной валюте, право на получение которой удостоверяет денежный инструмент, в пассажирской таможенной декларации указывается количество перемещаемых денежных инструментов (ст. 5).

На основании п. 2 Решения Комиссии Таможенного союза № 287 «Об утверждении формы пассажирской таможенной декларации и порядка заполнения пассажирской таможенной декларации» от 18 июня 2010 г. ${ }^{45}$ бланк пассажирской таможенной декларации состоит из основного формуляра и дополнительного формуляра «Декларация наличных денежных средств и (или) денежных инструментов» (декларация наличных денег), который является приложением к основному формуляру декларации. Декларация наличных денег заполняется при перемещении:

- наличных денежных средств (банкноты и монеты, за исключением монет из драгоценных металлов) и дорожных чеков в сумме, превышающей в эквиваленте 10000 долларов США;

- иных денежных инструментов в документарной форме (вексель, чеки (банковские), ценные бумаги на предъявителя, удостоверяющие обязательство эмитента (должника) по выплате денежных средств, в которых не указано лицо, которому осуществляется такая выплата).

При заполнении формуляра указываются сведения о всех перемещаемых наличных денежных средствах, дорожных чеках и денежных инструментах. Декларация наличных денег заполняется в двух экземплярах и подписывается декларантом. Дополнительно декларан-

\footnotetext{
${ }^{45}$ Настоящее решение вступило в силу с 06 июля 2010 г.
} 


\section{Системы стабилизации: финансовый контроль}

том проставляется дата заполнения формуляра. Один экземпляр декларации наличных денег совместно с основным формуляром декларации остается в таможенном органе. Второй экземпляр декларации наличных денег с соответствующей отметкой таможенного органа остается у декларанта (п. 24-25).

В контексте современной правовой регламентации валютного регулирования в России представляет несомненный интерес вопрос о незаконном перемещении валюты и валютных ценностей через таможенную границу Таможенного союза. Кодекс РФ об административный правонарушениях от 30 декабря 2001 г. в ред. от 02 апреля 2014 г. $^{46}$ (далее - КоАП РФ) содержит ст. 16.4. «Недекларирование либо недостоверное декларирование физическими лицами наличных денежных средств и (или) денежных инструментов», согласно которой недекларирование либо недостоверное декларирование физическими лицами наличных денежных средств и (или) денежных инструментов, перемещаемых через таможенную границу Таможенного союза и подлежащих письменному декларированию, если эти действия (бездействие) не содержат уголовно наказуемого деяния, влечет наложение административного штрафа на граждан в размере от однократной до двукратной незадекларированной суммы наличных денежных средств и (или) стоимости денежных инструментов либо конфискацию предмета административного правонарушения.

Примечания: 1. Для целей применения настоящей статьи незадекларированной признается сумма наличных денежных средств и (или) стоимость дорожных чеков сверх разрешенной таможенным законодательством Таможенного союза к ввозу (вывозу) без таможенного декларирования в письменной форме. 2. Пересчет наличных денежных средств, денежных инструментов в валюту РФ производится по действующему на день совершения или обнаружения административного правонарушения курсу Центрального банка РФ.

Уголовный кодекс РФ от 13 июня 1996 г. в ред. от 03 февраля 2014 г. ${ }^{47}$ (далее - УК РФ) содержит ст. 200.1. «Контрабанда наличных денежных средств и (или) денежных инструментов», согласно части первой которой незаконное перемещение через таможенную границу Таможенного союза в рамках ЕврАзЭС наличных денежных средств и (или) денежных инструментов, со-

${ }^{46}$ СЗ РФ. 2002. № 1. Ст. 1; 2014. № 14. Ст. 1561. Новая редакция КоАП РФ вступит в силу с 25 мая 2014 г.

${ }^{47}$ СЗ РФ. 1996. № 25. Ст. 2954; 2014. № 14. Ст. 1561. Новая редакция УК РФ вступит в силу с 05 июня 2014 г. вершенное в крупном размере, наказывается штрафом в размере от трехкратной до десятикратной суммы незаконно перемещенных наличных денежных средств и (или) стоимости незаконно перемещенных денежных инструментов или в размере заработной платы или иного дохода осужденного за период до двух лет, либо ограничением свободы на срок до двух лет, либо принудительными работами на срок до двух лет. Согласно части второй деяние, предусмотренное частью первой настоящей статьи, совершенное: а) в особо крупном размере; б) группой лиц, наказывается штрафом в размере от десятикратной до пятнадцатикратной суммы незаконно перемещенных наличных денежных средств и (или) стоимости незаконно перемещенных денежных инструментов или в размере заработной платы или иного дохода осужденного за период до трех лет, либо ограничением свободы на срок до четырех лет, либо принудительными работами на срок до четырех лет.

Примечания. 1. Деяние, предусмотренное настоящей статьей, признается совершенным в крупном размере, если сумма незаконно перемещенных наличных денежных средств и (или) стоимость незаконно перемещенных денежных инструментов превышает двукратный размер суммы наличных денежных средств и (или) стоимости дорожных чеков, разрешенных таможенным законодательством Таможенного союза в рамках ЕврАзЭС к перемещению без письменного декларирования. 2. Деяние, предусмотренное настоящей статьей, признается совершенным в особо крупном размере, если сумма незаконно перемещенных наличных денежных средств и (или) стоимость незаконно перемещенных денежных инструментов превышает пятикратный размер суммы наличных денежных средств и (или) стоимости дорожных чеков, разрешенных таможенным законодательством Таможенного союза в рамках ЕврАзЭС к перемещению без письменного декларирования. 3. При расчете размера суммы незаконно перемещенных наличных денежных средств и (или) стоимости незаконно перемещенных денежных инструментов из всей суммы незаконно перемещенных наличных денежных средств и (или) стоимости незаконно перемещенных денежных инструментов подлежит исключению та часть, которая таможенным законодательством Таможенного союза в рамках ЕврАзЭС разрешена к перемещению без декларирования или была задекларирована.

4. Лицо, добровольно сдавшее наличные денежные средства и (или) денежные инструменты, указанные в настоящей статье, освобождается от уголовной ответственности, если в его действиях не содержится иного состава преступления. Не могут признаваться добро- 


\section{Право и политика 5 (173) • 2014}

вольной сдачей наличных денежных средств и (или) денежных инструментов, указанных в настоящей статье, их обнаружение при применении форм таможенного контроля, их изъятие при задержании лица, а также при производстве следственных действий по их обнаружению и изъятию. 5. Под денежными инструментами в целях настоящей статьи понимаются дорожные чеки, векселя, чеки (банковские чеки), а также ценные бумаги в документарной форме, удостоверяющие обязательство эмитента (должника) по выплате денежных средств, в которых не указано лицо, которому осуществляется такая выплата ${ }^{48}$.

Следует обратить внимание на Письмо ФТС РФ № 01-11/30804 «О направлении информации об изменении ст. 16.4 КоАП РФ» от 18 июля 2013 г. ${ }^{49}$, в котором подчеркивается, что Федеральным законом «О внесении изменений в отдельные законодательные акты РФ в части противодействия незаконным финансовым операциям» от 28 июня 2013 г. изменена ст. 16.4 КоАП РФ и установлена уголовная ответственность за контрабанду наличных де-

\footnotetext{
${ }^{48}$ На содержание современных норм административного и уголовного законодательства, касающихся незаконного перемещения валюты и валютных ценностей, оказало существенное влияние Постановление Конституционного Суда РФ № 8-П по делу «О проверке конституционности положения части первой статьи 188 Уголовного кодекса РФ в связи с жалобой гражданки М.А. Асламазян» от 27 мая 2008 г. (Вестник Конституционного Суда РФ. 2008. № 4). Правовая позиция Конституционного Суда РФ и выявленный им конституционно-правовой смысл норм об уголовной ответственности за контрабанду, совершаемую путем перемещения через таможенную границу РФ недекларированной или недостоверно декларированной иностранной валюты и (или) валюты РФ, вероятно, оказали влияние на последующую декриминализацию ст. 188 УК РФ «Контрабанда». Согласно этому постановлению нормативное положение ч. 1 ст. 188 УК РФ в той мере, в какой оно позволяет при привлечении к уголовной ответственности за контрабанду, совершаемую путем перемещения через таможенную границу РФ недекларированной или недостоверно декларированной иностранной валюты и (или) валюты РФ в крупном (т.е. превышающем в эквиваленте 250000 рублей) размере, признавать его таковым исходя из всей перемещаемой суммы, включая и ту ее часть, которую закон разрешает ввозить в РФ без письменного декларирования, признано не соответствующим Конституции РФ. Конституционный Суд РФ указал, что допуская признание размера недекларированной или недостоверно декларированной валюты как крупного исходя из всей ввозимой суммы, включая ту ее часть, которую Ф3 «О валютном регулировании и валютном контроле» разрешает ввозить без письменного декларирования, указанное уголовно-правовое регулирование создает возможность расширительного толкования уголовного закона, которое влечет отягчение ответственности, а также применение мер уголовной ответственности, не адекватных общественной опасности совершенного деяния, являющегося, по существу, административным правонарушением (п. 5.3. Постановления КС РФ).

${ }^{49}$ Таможенные ведомости. 2013. № 11.
}

нежных средств и (или) денежных инструментов в крупном размере (ст. 200.1 УК РФ). Согласно новой редакции ст. 16.4 КоАП РФ за недекларирование либо недостоверное декларирование наличных денежных средств и (или) денежных инструментов физическое лицо может быть привлечено к административной ответственности при отсутствии признаков контрабанды. Для квалификации деяния физического лица как преступления либо административного правонарушения необходимо определить размер незадекларированных либо недостоверно задекларированных наличных денежных средств и (или) денежных инструментов.

Исходя из положений примечания 1 к ст. 16.4 КоАП РФ и примечания 3 к ст. 200.1 УК РФ при расчете размера незаконно перемещенной суммы наличных денежных средств и (или) стоимости дорожных чеков из всей незадекларированной суммы наличных денежных средств и (или) стоимости дорожных чеков исключается та часть, которая Договором о порядке перемещения физическими лицами наличных денежных средств и (или) денежных инструментов через таможенную границу Таможенного союза от 05 июля 2010 г. (далее Договор) разрешена к перемещению без письменного таможенного декларирования. В случае недостоверного декларирования рекомендуем следующее. Если недостоверно задекларированная сумма наличных денежных средств и (или) стоимость дорожных чеков меньше разрешенной Договором, то из всей перемещаемой суммы и (или) стоимости вычитается та часть, которую Договор разрешает ввозить (вывозить) без письменного таможенного декларирования. В случае же, когда недостоверно задекларированная часть больше разрешенной Договором, то вычету подлежит только задекларированная часть, а разрешенная Договором часть не вычитается.

При расчете размера денежных инструментов, за исключением дорожных чеков, из их стоимости так называемая разрешенная часть не вычитается, поскольку в соответствии с Договором их ввоз (вывоз) физическим лицом осуществляется при условии письменного таможенного декларирования вне зависимости от номинальной стоимости либо суммы в валюте государства - члена Таможенного союза или иностранной валюте, право на получение которой удостоверяет денежный инструмент. Для квалификации деяния физического лица как контрабанды крупным размером согласно примечанию 1 к ст. 200.1 УК РФ признается сумма незаконно перемещенных наличных денежных средств и (или) стоимость денежных инструментов, 


\section{Системы стабилизации: финансовый контроль}

превышающая двукратный размер суммы наличных денежных средств и (или) стоимости дорожных чеков, разрешенных Договором к перемещению без письменного декларирования.

При этом крупным размером денежных инструментов, подлежащих декларированию вне зависимости от их номинальной стоимости либо суммы и не относящихся к дорожным чекам, является стоимость, превышающая двукратный размер стоимости дорожных чеков, разрешенной Договором к перемещению без письменного декларирования. Обращаем внимание, что приостановление перемещения наличных денежных средств и (или) денежных инструментов в соответствии с Договором о противодействии легализации (отмыванию) доходов, полученных преступным путем, и финансированию терроризма при перемещении наличных денежных средств и (или) денежных инструментов через таможенную границу Таможенного союза от 19 декабря 2011 г. $^{50}$ не исключает принятие должностным лицом таможенного органа решения о возбуждении дела об административном правонарушении (уголовного дела) и изъятии (аресте) наличных денежных средств и (или) денежных инструментов.

Российское законодательство устанавливает запрет на пересылку наличной валюты РФ и иностранной валюты во внутренних и международных почтовых отправлениях ${ }^{51}$. Согласно ст. 22 (г) Федерального закона «О почтовой связи» от 17 июля 1999 г. в ред. от 06 декабря 2011 г. $^{52}$ и п. 17 Правил оказания услуг почтовой связи, утвержденных Постановлением Правительства РФ № 221 от 15 апреля $2005 \Gamma^{53}$ в почтовых отправлениях, пересылаемых в пределах РФ, запрещены к пересылке денежные знаки РФ и иностранная валюта (за исключением пересылаемых Банком России и его учреждениями). Аналогичное правило действует и в отношении международных почтовых отправлений.

Операторы почтовой связи имеют право задерживать внутренние почтовые отправления, содержимое которых запрещено к пересылке, в месте их обнаруже-

\footnotetext{
${ }^{50}$ БМД. 2013. № 10. С. 9-14. Настоящий договор вступил в силу с 20 февраля 2013 г. на территории государств - членов Таможенного союза ЕврАзЭС (России, Белоруссии и Казахстана).

${ }^{51}$ В целом под пересылкой понимается ввоз в РФ и вывоз из РФ товаров (в том числе наличной валюты и ценных бумаг) в несопровождаемом багаже без следования лица через таможенную границу РФ, а также в международных почтовых отправлениях.

${ }^{52}$ СЗ РФ. 1999. № 29. Ст. 3697; 2011. № 50. Ст. 7351. Новая редакция настоящего закона вступила в силу с 01 апреля 2013 г.

${ }^{53}$ С3 РФ. 2005. № 17. Ст. 1556. Настоящие правила вступили в силу с 01 мая 2005 г.
}

ния. О факте обнаружения в почтовых отправлениях запрещенного к пересылке вложения и задержания этих почтовых отправлений операторы почтовой связи обязаны немедленно ставить в известность соответствующие органы, уполномоченные производить изъятие запрещенных к пересылке предметов. Об указанном факте в отношении международных почтовых отправлений операторы почтовой связи обязаны информировать в 10-дневный срок отправителя или адресата, за исключением случаев, когда по факту обнаружения указанных предметов правоохранительными органами принимается решение о проведении оперативно-розыскных мероприятий (п. 49 Правил).

Важным представляется вопрос о переводах валюты РФ и иностранной валюты физическими лицами-резидентами из России за границу без открытия счета в уполномоченном банке. Согласно п. 1 Письма ЦБ РФ № 327-Т «О переводах денежных средств по поручению физических лиц без открытия банковских счетов» от 23 ноября $1998 \Gamma^{54}$ кредитные организации (за исключением небанковских кредитных организаций - организаций инкассации) вправе осуществлять операции по переводам денежных средств по поручению физических лиц без открытия банковских счетов на основании выданных Банком России лицензий, предусматривающих в числе разрешенных банковских операций операцию по кассовому обслуживанию физических и/или юридических лиц.

Согласно п. 1 Указания ЦБ РФ № 1412-У «Об установлении суммы перевода физическим лицом-резидентом из РФ без открытия банковских счетов» от 30 марта 2004 г. ${ }^{55}$ Банк России установил, что при осуществлении валютных операций физическое лицо-резидент имеет право перевести из РФ без открытия банковского счета в уполномоченном банке иностранную валюту или валюту РФ в сумме, не превышающей в эквиваленте 5 000 долларов США, определяемой с использованием официальных курсов иностранных валют к рублю, установленных Банком России на дату поручения уполномоченному банку на осуществление указанного перевода. Общая сумма переводов физического лица-резидента из РФ без открытия банковского счета, осуществляемых через уполномоченный банк (филиал уполномоченного банка) в течение одного операционного дня, не должна превышать в эквиваленте 5000 долларов США.

Настоящая статья подготовлена при поддержке Правовой информационно-справочной системы «Консультант Плюс».

\footnotetext{
${ }^{54}$ Вестник Банка России. 1998. № 84.

${ }^{55}$ Вестник Банка России. 2004. № 22.
} 


\section{Право и политика 5 (173) • 2014}

\section{Библиография:}

1. Алексеева Д.Г., Пыхтин С.В., Сапожников Н.В., Фальковская Я.М. Валютное право: Учебное пособие для магистров. М., 2013.

2. Зоркольцев Р.Д. Вексель в иностранной валюте: возможно ли свободное обращение среди резидентов? // Банковское дело. 2012. № 5.

3. Зоркольцев Р. Обращение векселей в иностранной валюте среди резидентов // Хозяйство и право. 2012. № 6 .

4. Ивашкова Т.В. Выявление и профилактика нарушений валютного законодательства // Международные банковские операции. 2011. № 1.

5. Кораблин В.В. Перспективы изменений в валютном законодательстве с учетом вступления Российской Федерации во Всемирную торговую организацию // Законодательство. 2013. № 2.

6. Кораблин В.В. Перспективы изменений в валютном законодательстве с учетом формирования Единого экономического пространства // Законодательство. 2013. № 4.

7. Красавина Л.Н. Актуальные проблемы валютной политики России // Банковское дело. 2013. № 3.

8. Крохина Ю.А. Актуальные проблемы законодательного обеспечения принципов валютного регулирования и валютного контроля // Российское правосудие. 2010. № 7.

9. Крохина Ю.А. (ред.) Валютное право: Учебник для магистров. М., 2013.

10. Миттельман К.Г. К вопросу о проблеме совершенствования понятийного аппарата валютного законодательства // Государство и право. 2012. № 8.

11. Степанченко А.В. К вопросу о залоге безналичной иностранной валюты // Банковское право. 2013. № 5.

12. Тедеев А.А. Тенденции формирования правовых принципов валютного регулирования // Евразийский юридический журнал. 2012. № 5.

13. А.А.Ситник Валютное регулирование в Российской Федерации: история современности и дальнейшие направления совершенствования валютного законодательства // Финансовое право и управление. - 2013. - 1. - C. 79-87. DOI: 10.7256/.2013.1.9522.

14. Хаменушко И.В. О необходимости учета взаимосвязи валютного регулирования с бюджетным правом для правильного понимания отраслевой принадлежности валютного регулирования // Финансовое право и управление. - 2014. - 1. - С. 75 82. DOI: 10.7256/2310-0508.2014.1.9892.
15. Гетьман-Павлова И.В.. Международное частное право России, Франции и Европейского Союза: новые горизонты для совместного правосудия (обзор научно-исследовательского проекта Национального исследовательского университета «Высшая школа экономики» и Университета Париж 1 Пантеон-Сорбонна) // Международное право и международные организации / International Law and International Organizations. - 2014. - № 1. C. 104-107. DOI: 10.7256/2226-6305.2014.1.11537

16. Ерпылева Н.Ю.. Международное чековое право и российское законодательство: основные категории и механизмы регулирования чековых отношений // Международное право и международные организации / International Law and International Organizations. - 2014. - № 1. - C. 104-107. DOI: 10.7256/2226-6305.2014.1.11578

17. Н.Ю. Ерпылева. Организационно-правовые формы трансграничного движения капитала в российской банковской системе // Право и политика. - 2013. - № 4. - C. 104-107. DOI: 10.7256/18119018.2013.04.9

18. О.В. Болтинова. К вопросу о государственном финансовом контроле в Российской Федерации // Финансовое право и управление. - 2013. - № 2. C. 39-45. DOI: 10.7256/2310-0508.2013.2.9725.

19. А.В. Левитский. Финансовый контроль в России в условиях вступления в ВТО // Финансовое право и управление. - 2013. - № 2. - С. 60-67. DOI: 10.7256/2310-0508.2013.2.9727.

20. Н. Ю. Ерпылева. Нормативный состав международного частного права и его соотношение с внутригосударственным и международным публичным правом // Международное право и международные организации / International Law and International Organizations. - 2011. - № 2 .

21. Хаменушко И.В.. О необходимости учета взаимосвязи валютного регулирования с бюджетным правом для правильного понимания отраслевой принадлежности валютного регулирования // Финансовое право и управление. - 2014. - № 1. C. 75-82. DOI: 10.7256/2310-0508.2014.1.9892.

22. А.А.Ситник. Валютное регулирование в Российской Федерации: история современности и дальнейшие направления совершенствования валютного законодательства // Финансовое право и управление. - 2013. - № 1. - C. 79-87. DOI: $10.7256 / .2013 .1 .9522$

23. А.А.Ситник Валютное регулирование в Российской Федерации: история современности и 
дальнейшие направления совершенствования валютного законодательства // Финансовое право и управление. - 2013. - 1. - C. 79 - 87. DOI: 10.7256/.2013.1.9522.

24. Хаменушко И.В. О необходимости учета взаимосвязи валютного регулирования с бюджетным правом для правильного понимания отраслевой принадлежности валютного регулирования // Финансовое право и управление. - 2014. - 1. - С. 75 - 82. DOI: 10.7256/2310-0508.2014.1.9892.

25. Яворская М.В. Регулирование финансового сектора в условиях кризиса // NB: Экономика, тренды и управление. - 2013. - 1. - C. 91 - 110. DOI: 10.7256/2306-4595.2013.1.577. URL: http://www.enotabene.ru/etc/article_577.html

\section{References (transliteration):}

1. Alekseeva D.G., Pykhtin S.V., Sapozhnikov N.V., Fal'kovskaya Ya.M. Valyutnoe pravo: Uchebnoe posobie dlya magistrov. M., 2013.

2. Zorkol'tsev R.D. Veksel' v inostrannoi valyute: vozmozhno li svobodnoe obrashchenie sredi rezidentov? // Bankovskoe delo. 2012. № 5.

3. Zorkol'tsev R. Obrashchenie vekselei v inostrannoi valyute sredi rezidentov // Khozyaistvo i pravo. 2012. № 6.

4. Ivashkova T.V. Vyyavlenie i profilaktika narushenii valyutnogo zakonodatel'stva // Mezhdunarodnye bankovskie operatsii. 2011. № 1 .

5. Korablin V.V. Perspektivy izmenenii v valyutnom zakonodatel'stve s uchetom vstupleniya Rossiiskoi Federatsii vo Vsemirnuyu torgovuyu organizatsiyu // Zakonodatel'stvo. 2013. № 2 .

6. Korablin V.V. Perspektivy izmenenii v valyutnom zakonodatel'stve s uchetom formirovaniya Edinogo ekonomicheskogo prostranstva // Zakonodatel'stvo. 2013. № 4.

7. Krasavina L.N. Aktual'nye problemy valyutnoi politiki Rossii // Bankovskoe delo. 2013. № 3.

8. Krokhina Yu.A. Aktual'nye problemy zakonodatel'nogo obespecheniya printsipov valyutnogo regulirovaniya i valyutnogo kontrolya // Rossiiskoe pravosudie. 2010. № 7 .

9. Krokhina Yu.A. (red.) Valyutnoe pravo: Uchebnik dlya magistrov. M., 2013.

10. Mittel'man K.G. K voprosu o probleme sovershenstvovaniya ponyatiinogo apparata valyutnogo zakonodatel'stva // Gosudarstvo i pravo. 2012. № 8.
11. Stepanchenko A.V. K voprosu o zaloge beznalichnoi inostrannoi valyuty // Bankovskoe pravo. 2013. № 5.

12. Tedeev A.A. Tendentsii formirovaniya pravovykh printsipov valyutnogo regulirovaniya // Evraziiskii yuridicheskii zhurnal. 2012. № 5.

13. A.A.Sitnik Valyutnoe regulirovanie $\mathrm{V}$ Rossiiskoi Federatsii: istoriya sovremennosti i dal'neishie napravleniya sovershenstvovaniya valyutnogo zakonodatel'stva // Finansovoe pravo i upravlenie. - 2013. - 1. - C. 79-87. DOI: 10.7256/.2013.1.9522.

14. Khamenushko I.V. O neobkhodimosti ucheta vzaimosvyazi valyutnogo regulirovaniya s byudzhetnym pravom dlya pravil'nogo ponimaniya otraslevoi prinadlezhnosti valyutnogo regulirovaniya // Finansovoe pravo i upravlenie. - 2014. - 1. - C. 75-82. DOI: 10.7256/2310-0508.2014.1.9892.

15. Get'man-Pavlova I.V.. Mezhdunarodnoe chastnoe pravo Rossii, Frantsii i Evropeiskogo Soyuza: novye gorizonty dlya sovmestnogo pravosudiya (obzor nauchno-issledovatel'skogo proekta Natsional'nogo issledovatel'skogo universiteta «Vysshaya shkola ekonomiki» i Universiteta Parizh 1 Panteon-Sorbonna) // Mezhdunarodnoe pravo i mezhdunarodnye organizatsii / International Law and International Organizations. - 2014. - № 1. - S. 104-107. DOI: 10.7256/2226-6305.2014.1.11537

16. Erpyleva N.Yu.. Mezhdunarodnoe chekovoe pravo i rossiiskoe zakonodatel'stvo: osnovnye kategorii i mekhanizmy regulirovaniya chekovykh otnoshenii // Mezhdunarodnoe pravo i mezhdunarodnye organizatsii / International Law and International Organizations. - 2014. - № 1. - S. 104-107. DOI: 10.7256/22266305.2014.1.11578

17. N.Yu. Erpyleva. Organizatsionno-pravovye formy transgranichnogo dvizheniya kapitala $\mathrm{v}$ rossiiskoi bankovskoi sisteme // Pravo i politika. 2013. - № 4. - S. 104-107. DOI: 10.7256/18119018.2013 .04 .9

18. O.V. Boltinova. K voprosu o gosudarstvennom finansovom kontrole v Rossiiskoi Federatsii // Finansovoe pravo i upravlenie. - 2013. - № 2. - S. 39-45. DOI: 10.7256/2310-0508.2013.2.9725.

19. A.V. Levitskii. Finansovyi kontrol' v Rossii v usloviyakh vstupleniya v VTO // Finansovoe pravo i upravlenie. - 2013. - № 2. - S. 60-67. DOI: 10.7256/23100508.2013.2.9727.

20. N. Yu. Erpyleva. Normativnyi sostav mezhdunarodnogo chastnogo prava i ego sootnoshenie s vnutrigosudarstvennym i mezhdunarodnym publichnym pravom // Mezhdunarodnoe pravo i mezhdunarodnye 
DOI: $10.7256 / 1811-9018.2014 .5 .11920$

При цитировании этой статьи сноска на dоі обязательна

\section{Право и политика 5 (173) 2014}

organizatsii / International Law and International Organizations. - 2011. - № 2 .

21. Khamenushko I.V.. O neobkhodimosti ucheta vzaimosvyazi valyutnogo regulirovaniya s byudzhetnym pravom dlya pravil'nogo ponimaniya otraslevoi prinadlezhnosti valyutnogo regulirovaniya // Finansovoe pravo i upravlenie. - 2014. - № 1. - S. 75-82. DOI: 10.7256/2310-0508.2014.1.9892.

22. A.A.Sitnik. Valyutnoe regulirovanie v Rossiiskoi Federatsii: istoriya sovremennosti i dal'neishie napravleniya sovershenstvovaniya valyutnogo zakonodatel'stva // Finansovoe pravo i upravlenie. - 2013. - № 1. - S. 79-87. DOI: 10.7256/.2013.1.9522

23. A.A.Sitnik Valyutnoe regulirovanie v Rossiiskoi Federatsii: istoriya sovremennosti i dal'neishie napravleniya sovershenstvovaniya valyutnogo zakonodatel'stva // Finansovoe pravo i upravlenie. 2013. - 1. - C. 79 - 87. DOI: 10.7256/.2013.1.9522.

24. Khamenushko I.V. O neobkhodimosti ucheta vzaimosvyazi valyutnogo regulirovaniya $\mathrm{s}$ byudzhetnym pravom dlya pravil'nogo ponimaniya otraslevoi prinadlezhnosti valyutnogo regulirovaniya // Finansovoe pravo i upravlenie. - 2014. - 1. - C. 75 - 82. DOI: 10.7256/23100508.2014.1.9892.

25. Yavorskaya M.V. Regulirovanie finansovogo sektora v usloviyakh krizisa // NB: Ekonomika, trendy i upravlenie. - 2013. - 1. - C. $91-110$. DOI: 10.7256/2306-4595.2013.1.577. URL: http:// www.e-notabene.ru/etc/article_577.html 